\title{
Assessment of the Diversity of Macro Aquatic Species in Amburayan River in Kapangan, Benguet in the Philippines
}

\author{
Marx Perfecto C. Garcia1, Annie Melinda Paz-Alberto², Tereso A. Abella², Chito F. Sace², \\ Eric G. Claudio ${ }^{3}$, Arneil G. Gabriel ${ }^{4}$

\begin{abstract}
${ }^{1}$ Bureau of Fisheries and Aquatic Resources, Regional Office 1, Cordillera Administrative Region, Baguio City, Philippines ${ }^{2}$ Central Luzon State University, Muñoz City, Philippines

${ }^{3}$ Nueva Ecija University of Science and Technology, Cabanatuan City, Philippines

${ }^{4}$ Department of Public Administration Nueva Ecija University of Science and Technology, Cabanatuan City, Philippines

Email: gabrielarneil77@gmail.com
\end{abstract}

How to cite this paper: Garcia, M.P.C., Paz-Alberto, A.M., Abella, T.A., Sace, C.F., Claudio, E.G. and Gabriel, A.G. (2018) Assessment of the Diversity of Macro Aquatic Species in Amburayan River in Kapangan, Benguet in the Philippines. Open Journal of Marine Science, 8, 323-354.

https://doi.org/10.4236/ojms.2018.83018

Received: January 1, 2018

Accepted: May 14, 2018

Published: May 17, 2018

Copyright $(9) 2018$ by authors and Scientific Research Publishing Inc. This work is licensed under the Creative Commons Attribution International License (CC BY 4.0).

http://creativecommons.org/licenses/by/4.0/

\begin{abstract}
Little is known about the diversity and status of endemic freshwater fishes which are valuable bio-indicators of ecosystem health and an integral part of a country's natural heritage. Some of the less studied areas in the Philippines are the river systems in the Cordillera which are equally important as that of the other freshwater systems in the country. Amburayan River in Kapangan, Benguet is one of the rivers in the said region. Thus assessment study of the diversity of macro aquatic species was conducted to provide a baseline data in the formulation of resource management strategies and polices. By using a mixture of qualitative and quantitative research methods, the study determined and identified the presence of macro species in the study area. It applied the National Stock Assessment Program (NSAP) procedures in the gathering of samples while identification and determination of fish stocks were done by morphometric analysis of the catch with the help of available references and assistance of experts. This is later verified through submission of samples to the National Fisheries Research Development Institute (NFRDI) as part of the NSAP areas for DNA analysis. The measurement of the impacts of human activities to the river systems was done using the checklist method by Smith and Smith. The study found that there is low biodiversity of macro aquatic species in the area because of the presence of introduced species, illegal fishing practices, quarrying and mining activities. There are also no indigenous or traditional management measures conducted to conserve the river ecosystem biodiversity. The study recommended that similar study be done in other areas of the river and that the government agencies to undertake fishe-
\end{abstract}


ries programs which would regulate the exploitation and utilization and allow regeneration of macro aquatic species in the river system.

\section{Keywords}

Assessment Study, Macro Aquatic Species, River System, The Philippines

\section{Introduction}

Cordillera is described as a region with mountainous topography characterized by towering peaks, plateaus and intermittent patches of valleys [1]. It is located in the north-central part of Luzon and is bounded by Ilocos Norte and Cagayan in the north, Pangasinan and Nueva Ecija in the south, Cagayan Valley in the east and Ilocos Region in the west [2]. Cordillera is the country's only land-locked region. It is deficient in coastal and marine resources that are supposed to supply the bulk source of fisheries commodities for the local community. The topography of the region made fishery resources consist primarily of inland waters. All are freshwater ecosystems which are limited of aquatic species (in terms of catch volume) that are utilized as food by the Cordillerans. Apparently, fish provides $15 \%$ of the total animal protein in human diets and the primary source of livelihood for 35 million people; $30 \mathrm{M}$ in Asia and 2.6 M in Africa [3]. Inland waters and freshwater biodiversity constitute a valuable natural resource, in economic, cultural, aesthetic, scientific and educational terms [4]. The streams and lakes of the Philippines' freshwater ecoregion support high numbers of endemic species, particularly fish [5] as cited [6] that in 1990s, the total number of freshwater fish species is 260 . However, Barut [7] stated that 330 species are Philippine endemics, of which, 48 genera and 127 are goby species. It is expected that as the assessment activities on the freshwater resources of the country is continuous, new species of aquatic organisms especially those that abounds the Cordillera region will be identified.

The Cordillera is dubbed as the "Watershed Cradle of the North"-as it hosts nine major rivers that provide continuous water for irrigation and energy for Northern Luzon. Eight of these rivers are identified by the Department of Environment and Natural Resources-Cordillera Administrative Region (DENR-CAR) [8] namely: Abra River, Abulog-Apayao River, Agno River, Amburayan River, Bued River, Chico River, Nanguilian River and Siffu-Mallig River. Ibulao River in Ifugao is one of these rivers which supports water supply for the Magat Dam in which is located in some parts of Ifugao and Isabela. Three other dams are also supplied by the Cordillera River systems namely are Ambuklao Dam in Bokod, Binga Dam in Itogon and San Roque Dam in some parts of Benguet and Pangasinan.

These river systems serve as fishing grounds of endemic, migratory and indigenous aquatic species which is manifested by the presence of fishermen in the 
rivers and observed multi-species catch sold in the markets, respectively.

Local fishermen utilize the rivers as areas for livelihood activities and alternative source of food for their families. These are also exploited for eco-tourism purposes such as swimming and white water rafting. In addition [9], these inland water bodies are not only important for fisheries, irrigation, hydroelectric power generation and other uses of man but for a "vital part of nature's pathway for the circulation of water on the planet". These resources carry great roles in the systemic, routinely and necessary processes on earth.

The river system is a lotic freshwater ecosystem rich in high-value fish species such as eels, gobies, and mullets. These include the most expensive freshwater fish that thrives in the upstream of the Abra River within the vicinity of its watershed areas [10]. Many local people depend on the said rivers especially those that are in the remote areas of the region [11]. Most authors agree that inland fisheries are important to food security. However, fishermen claimed that indigenous aquatic species that used to abound the rivers are decreasing over the years [12].

\subsection{Statement of the Problem}

Little is known about the diversity and status of endemic freshwater fishes which are equally valuable as bio-indicators of ecosystem health and an integral part of our country's natural heritage [13] that there are many unique species of freshwater fishes but their status is not known.

Therefore, there is a need to conduct immediate assessment of these ecosystems to monitor their presence in isolated rivers and lakes thereby counterbalance the decreasing fish catch and stocks. In line with this, [14] said that states (government) should assign priority research and data collection in order to improve scientific and technical knowledge of fisheries including their interaction with the ecosystem.

In the Philippines, research and survey activities of fresh water fishes are also encouraged not only for scientific, technological and educational purposes that would also benefit Filipino citizens (RA 8550), but also for regulations (Section 7); utilization (Section 8); conservation and rehabilitation (Section 11).

As part of the baseline information; inventory, identification or survey of the aquatic species is considered necessary to the local community, understanding of the ecosystem, for policy formulation and sustainable water resources management.

This study covers the first phase of assessment for the water resources and its stocks. It provides that baseline information and data that are significant in the assessment of resources. It identifies and determines the stocks in the river systems of the Cordillera that support the fish utilization and consumption of the immediate community.

\subsection{Objectives of the Study}

1) To survey and identify macro aquatic species present in Amburayan River 
in Kapangan, Benguet;

2) To determine and assess the possible threats (environmental and anthropogenic factors) that affect the ecological integrity of the Amburayan River ecosystem in Kapangan, Benguet;

3) To determine and document the indigenous conservation measures of biodiversity and river ecosystem and;

4) To give potential recommendations, management and conservation measures and policies that would maintain the ecological integrity of the river ecosystem and attain sustainable resource utilization.

\subsection{Time and Place of the Study}

The study was conducted in Amburayan River, Kapangan, Benguet from December 2014 to February 2015. It is an identified fishing ground on the expansion of the National Stock Assessment Program (NSAP) in Cordillera Administrative Region (CAR) for data gathering and recording. Kapangan, Benguet has a total population of 20,084 as of May 01, 2012 [15]. It caters an estimated length of $9323 \mathrm{~m}$ of the Amburayan River from Atok, Benguet (16 36'39.03"N, $120^{\circ} 38^{\prime} 18.14^{\prime \prime} \mathrm{E}$ with estimated elevation of $1835 \mathrm{ft}$ ) to La Union Province $\left(16^{\circ} 39^{\prime} 37.73^{\prime \prime} \mathrm{N}, 120^{\circ} 34^{\prime} 59.36^{\prime \prime} \mathrm{E}\right.$ with estimated elevation of $\left.1,316 \mathrm{ft}\right)$ boundaries (Google Earth Pro). However, data gathering was concentrated in Barangay Cuba, Kapangan, Benguet $\left(16^{\circ} 36^{\prime} 56.48^{\prime \prime} \mathrm{N}, 120^{\circ} 37^{\prime} 28.27^{\prime \prime} \mathrm{E}\right.$ with estimated elevation of $1702 \mathrm{ft}$ ) with a total population of 995 as of May 01, 2010. Barangay Cuba, Benguet has a Type I Climate among the four types of climate in the Philippines. It has two pronounced seasons; the wet and dry season, which is experienced from November to April and May to October, respectively.

Three municipalities of Benguet encompass the Amburayan River. These are Kapangan, Atok and Kibungan with populations of 20,084, 19,242 and 16,850, respectively as of May 01, 2010 (PSGC, 2014). Headwaters of the river are found in Atok and Kibungan. Water that flows in the rivers of these municipalities drains to the river in Kapangan before it joints to its downstream in La Union. However, another tributary was observed in Kibungan that directly connects the Amburayan River in the Province of La union (Google Earth Pro). The connection of the upstream and downstream tributaries of the Amburayan River was reviewed with the use of Google Earth Pro application.

\section{Methodology}

\subsection{Sampling Stations}

In order to gather firsthand information from the fishermen in the place, as it is shown in Figure 1, conduct of Focused Group Discussion (FGD) was done. The FGD was used to generate additional information that are more specific to the community's utilization of the Amburayan River, how the river influences their socio-economic aspects and understand the need of the fishing community for 


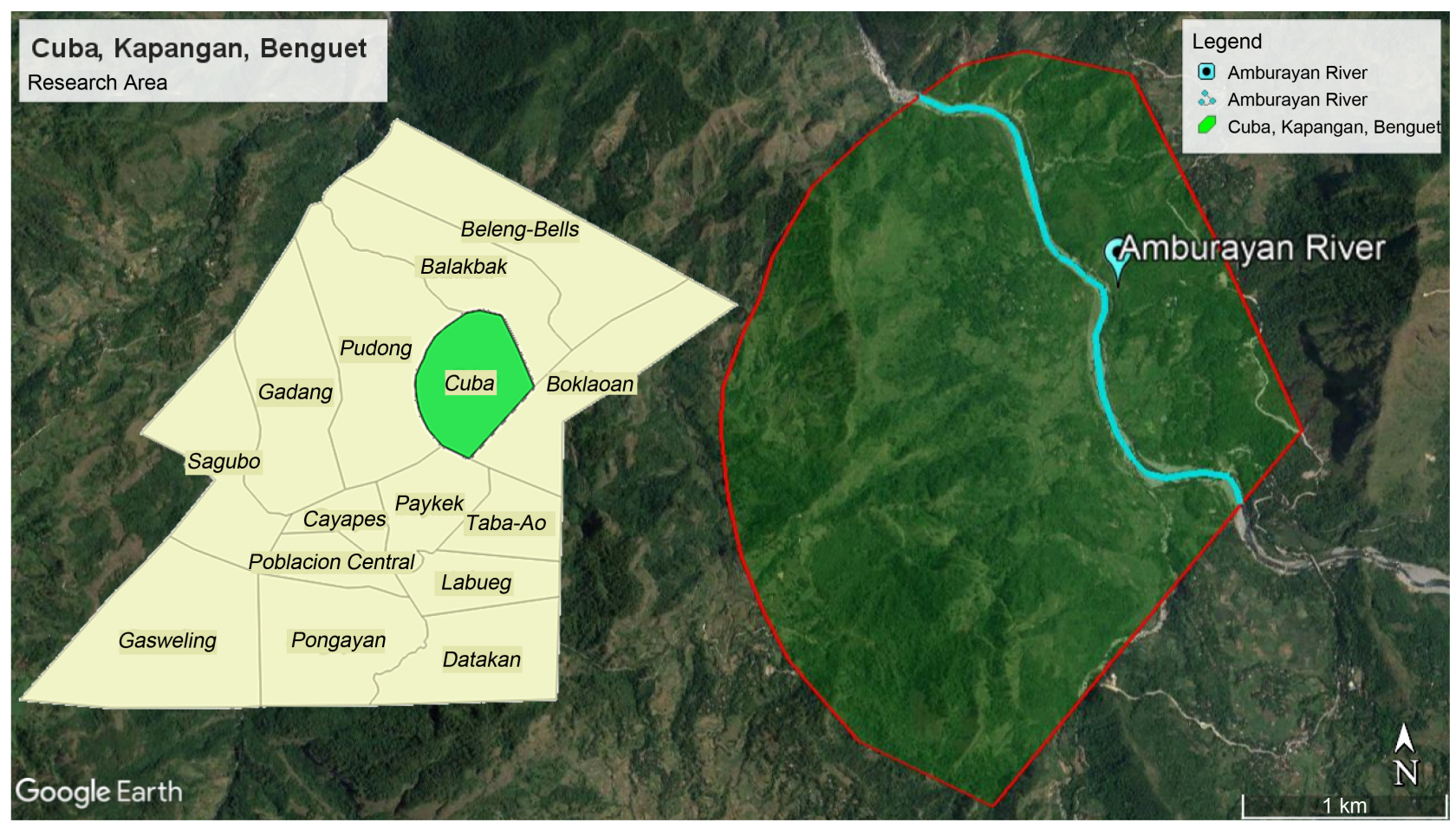

Figure 1. Location of the study site in Amburayan River in Cuba, Kapangan, Benguet (Source: Google Earth Pro and Quantum GIS).

rural development. It also assisted in identifying the problems encountered that adversely affect not only the fishing community but the river ecosystem in general and their respective potential solutions.

The five sampling sites were also identified during the conduct of the FGD. These are some of the areas that the fishermen in the locality suggested and selected as areas for sampling because it is also their fishing sites. In addition to this, assignment of potential sampling stations was made, making it sure that different types of niches were included (Alberto, 2005). Thus, groups of fishermen were assigned to conduct their fishing activities in their respective sites from the identified sampling areas.

Each station was laid with five quadrats measuring $10 \mathrm{~m} \times 12 \mathrm{~m}$. Each station catered $600 \mathrm{~m}^{2}$ and the use of measuring tape and GPS facilitated the measurement and geo-tagging of the stations, respectively. Sampling in each of the station was done three times.

The water quality parameters of the sampling stations were also determined with the use of DO meter and LaMotte Water Quality Kit. Parameters such as $\mathrm{DO}, \mathrm{pH}$, temperature, alkalinity, hardness, carbon dioxide and ammonia were generated from this water quality kit and instrument.

Water quality gathering of the stations were conducted three times from January to February 2015. All of the water quality parameters that were gathered were in the optimum ranges for the macro aquatic species in the Amburayan River to thrive and survive. The water quality parameters are shown in Table 1. 
Table 1. Water quality parameters of the stations.

\begin{tabular}{|c|c|c|c|c|}
\hline \multirow[b]{2}{*}{ PARAMETERS } & \multirow[b]{2}{*}{ STATION } & \multicolumn{3}{|c|}{ SAMPLING } \\
\hline & & $\begin{array}{c}1 \text { st } \\
(1 / 15 / 2015)\end{array}$ & $\begin{array}{c}\text { 2nd } \\
(1 / 25 / 2015)\end{array}$ & $\begin{array}{c}\text { 3rd } \\
(2 / 5 / 2015)\end{array}$ \\
\hline \multirow{5}{*}{$\begin{array}{l}\text { Dissolved Oxygen } \\
(\mathrm{mg} / \mathrm{L})\end{array}$} & 1 & 7.02 & 7.17 & 7.20 \\
\hline & 2 & 7.77 & 7.61 & 7.52 \\
\hline & 3 & 7.84 & 7.70 & 7.88 \\
\hline & 4 & 7.78 & 7.75 & 7.68 \\
\hline & 5 & 7.39 & 7.53 & 7.59 \\
\hline \multirow{5}{*}{ Temperature $\left({ }^{\circ} \mathrm{C}\right)$} & 1 & 18.40 & 18.00 & 18.30 \\
\hline & 2 & 18.60 & 18.10 & 18.40 \\
\hline & 3 & 19.00 & 18.50 & 19.10 \\
\hline & 4 & 19.40 & 18.90 & 19.40 \\
\hline & 5 & 20.80 & 20.50 & 20.60 \\
\hline \multirow{5}{*}{$\mathrm{pH}(\mathrm{ppm})$} & 1 & 8.00 & 7.50 & 7.60 \\
\hline & 2 & 7.90 & 7.70 & 7.40 \\
\hline & 3 & 8.10 & 7.40 & 7.90 \\
\hline & 4 & 7.40 & 7.00 & 7.70 \\
\hline & 5 & 7.40 & 8.40 & 7.90 \\
\hline \multirow{5}{*}{ Hardness (ppm) } & 1 & 100.00 & 100.00 & 110.00 \\
\hline & 2 & 100.00 & 95.00 & 145.00 \\
\hline & 3 & 120.00 & 95.00 & 105.00 \\
\hline & 4 & 115.00 & 105.00 & 105.00 \\
\hline & 5 & 95.00 & 80.00 & 125.00 \\
\hline \multirow{5}{*}{ Alkalinity (ppm) } & 1 & 60.00 & 70.00 & 60.00 \\
\hline & 2 & 60.00 & 65.00 & 105.00 \\
\hline & 3 & 60.00 & 60.00 & 55.00 \\
\hline & 4 & 60.00 & 60.00 & 65.00 \\
\hline & 5 & 75.00 & 70.00 & 60.00 \\
\hline \multirow{5}{*}{$\mathrm{CO}_{2}(\mathrm{ppm})$} & 1 & 1.00 & 1.00 & 0.00 \\
\hline & 2 & 1.00 & 1.00 & 1.00 \\
\hline & 3 & 1.00 & 1.00 & 1.00 \\
\hline & 4 & 1.00 & 1.00 & 1.00 \\
\hline & 5 & 1.00 & 0.00 & 0.00 \\
\hline \multirow{5}{*}{ Nitrate/Nitrite (ppm) } & 1 & 0.00 & 0.00 & 0.00 \\
\hline & 2 & 0.00 & 0.00 & 0.00 \\
\hline & 3 & 0.00 & 0.00 & 0.00 \\
\hline & 4 & 0.00 & 0.00 & 0.00 \\
\hline & 5 & 0.00 & $<.05$ & 0.00 \\
\hline \multirow{5}{*}{$\mathrm{NH}_{3}(\mathrm{ppm})$} & 1 & $<0.20$ & $<0.20$ & $<0.20$ \\
\hline & 2 & $<0.20$ & $<0.20$ & $<0.20$ \\
\hline & 3 & $<0.20$ & $<0.20$ & $<0.20$ \\
\hline & 4 & $<0.20$ & $<0.20$ & $<0.20$ \\
\hline & 5 & $<0.20$ & $<0.20$ & $<0.20$ \\
\hline
\end{tabular}




\subsection{Methods of Sample Collection}

Macro aquatic species were collected with the use of traditional and customized fishing gears. Sampling schedule followed the procedure of National Stock Assessment Program (NSAP) (NSAP, 2014. National Stock Assessment Program (NSAP) Standard Training for Enumerators. Module 3: Fish Catch Monitoring and Sampling Methods. 56 Slides). The standard sampling frequency was every after two days regardless of weekends and holidays. Data collection method was also adopted from the NSAP. The procedure applied is as follows:

1) Interview of fishermen was conducted

2) Determination of the total weight of catch was done

3) Set aside a representative sub-sample and record sub-sample weight of species

4) Sort by species

5) Weighing by species group

6) Measurement of the sizes by species group

7) In addition, collection of samples in the assigned sampling stations outside the regular fishing areas of the fishermen were also conducted on scheduled basis with reference to the sampling schedule and methods of NSAP

\subsection{Identification and Documentation of Macro Aquatic Species}

The identification and determination of Macro Aquatic Species was done by the use of available references and assistance of experts. The macro aquatic species that need further identification were submitted to NFRDI for proper nomenclature using DNA barcoding. Species identification was done by a Fisheries Technologist of the Institute and the Bureau of Fisheries and Aquatic Resources-Cordillera Administrative Region (BFAR-CAR). Result of the DNA Analysis and Certificate of Identification of Species were requested as proof of identification. Meanwhile, the evaluation of ecological factors of the samples was determined using the Smith \& Smith (1998) formulas as cited by Alberto [16].

\subsection{Determination of the Threats and Level of Impact on the Anthropogenic Activities in the River}

A checklist was utilized to determine and assess the threats to the river ecosystem caused by anthropogenic activities. This was conducted by the researchers together with the representatives from the Municipal Local Government Unit (MLGU) of Kapangan, Barangay Cuba and BFAR-CAR. Ten fishermen composed the Focus Group Discussion (FGD).

There were four levels of impacts in each source of environmental degradation, and a value was assigned for each of the level. The value, impact level and impact estimate are presented in Table 2.

To get the mean of sum of respondents, the sum of the answers for each level was divided to the total number of respondents and a scale was used to interpret the scores in the level of impacts on the environmental degradation of the river 
Table 2. Matrix on the value, impact level and impact estimate of the sources of environmental degradation.

\begin{tabular}{ccc}
\hline VALUE & IMPACT LEVEL & IMPACT ESTIMATE (\%) \\
\hline 1 & no significant impact & $0-5$ \\
2 & small impact & $6-25$ \\
3 & moderate impact & $26-49$ \\
4 & major impact & 50 and above \\
\hline
\end{tabular}

ecosystem. This scale is presented in Table 3.

\subsection{Determination of the Conservation Measures of Biodiversity and River Ecosystem}

The available indigenous conservation measures of biodiversity and river ecosystem were determined during the conduct of the FGD.

\subsection{Statistical Treatment of Data}

Simple statistical analysis was administered to the catch data. Statistics on the volume of catch, percent composition (in terms of biomass and population), weighted mean and ranking of macro aquatic species identified were made. Simple descriptive analysis was prepared to characterize the biological parameters of the Amburayan River in Kapangan, Benguet with concern to the available macro aquatic species inhabiting on it. The collected samples also determined the biodiversity of the river and its productivity.

\section{Results and Discussion}

\subsection{Survey and Identification of Macro Aquatic Species in Amburayan River, Kapangan, Benguet}

There were 14 species of macro aquatic species caught in Amburayan River in Kapangan, Benguet. All of which are aquatic fauna since macrophytes were absent within the water column of the river. Some of the reasons are: 1) the environment is a lotic ecosystem and the water is continuously flowing from the headwaters to its downstream preventing the growth and proliferation of macrophytes in the water; and 2) the composition of the river's substrate or basin is a mixture of large boulders, gravels and huge rocks which are not fertile and do not support the growth of macro aquatic plants.

The samples are composed of nine finfish species (five goby species, two eel species, one cichlid species and one live bearer species), four crustacean species (three freshwater prawn species) including one freshwater crab (Sundathelphusa sp.) and one gastropod species (Melanoidesmaculata.). Most of the macro aquatic organisms that were caught are native or indigenous in the area. Only the tilapia (Oreochromisniloticus) and mosquito fish (Gambussiaaffinis) were found to be introduced in the ecosystem. 
Table 3. Matrix on the scale and level of impact of the environmental degradation.

\begin{tabular}{cc}
\hline SCALE & LEVEL OF IMPACT \\
\hline $1.01-1.75$ & no significant impact \\
$1.76-2.50$ & small impact \\
$2.51-3.25$ & moderate impact \\
$3.26-4.00$ & major impact \\
\hline
\end{tabular}

The following are the macro aquatic species present in Amburayan River in Kapangan, Benguet:

$\begin{array}{ll}\text { 1) Gambussiaaffinis } & \text { (Figure 2) } \\ \text { Kingdom: } & \text { Animalia } \\ \text { Phylum: } & \text { Chordata } \\ \text { Class: } & \text { Actinopterygii } \\ \text { Order: } & \text { Cyprinidontiformes } \\ \text { Family: } & \text { Poeciliidae } \\ \text { Genus. } & \text { Gambussia } \\ \text { Species: } & \text { affinis } \\ \text { Common Name: } & \text { Mosquito Fish } \\ \text { Local Name: } & \text { Tamtampi } \\ \text { Description: } & \end{array}$

Dorsal spines (total): 0; Dorsal soft rays (total): 7 - 9; Anal spines: 0; Anal soft rays: 9 - 10. Origin of dorsal fin opposite 7th anal ray. Length of anal base much less than half distance from caudal. 8 horizontal scale rows between back and abdomen. Ventrals terminate immediately before anal fin. Pelvic fins reach ventrals (Froese and Pauly, 2014).

2) Oreochromis nilotocus (Figure 3)

$\begin{array}{ll}\text { Kingdom: } & \text { Animalia } \\ \text { Phylum: } & \text { Chordata } \\ \text { Class: } & \text { Actinopterygii } \\ \text { Order: } & \text { Perciformes } \\ \text { Family: } & \text { Cichlidae } \\ \text { Genus: } & \text { Oreochromis } \\ \text { Species: } & \text { niloticus } \\ \text { Common Name: } & \text { Nile Tilapia } \\ \text { Local Name: } & \text { Tilapia } \\ \text { Description: } & \end{array}$

Dorsal spines (total): 15 - 18; Dorsal soft rays (total): 11 - 13; Anal spines: 3; Anal soft rays: 9 - 11; Vertebrae: 30 - 32. Diagnosis: jaws of mature male not greatly enlarged (length of lower jaw $29 \%$ - 37\% of head length); genital papilla of breeding male not tassellate. Most distinguishing characteristic is the presence of regular vertical stripes throughout depth of caudal fin (Froese and Pauly, 2014). 


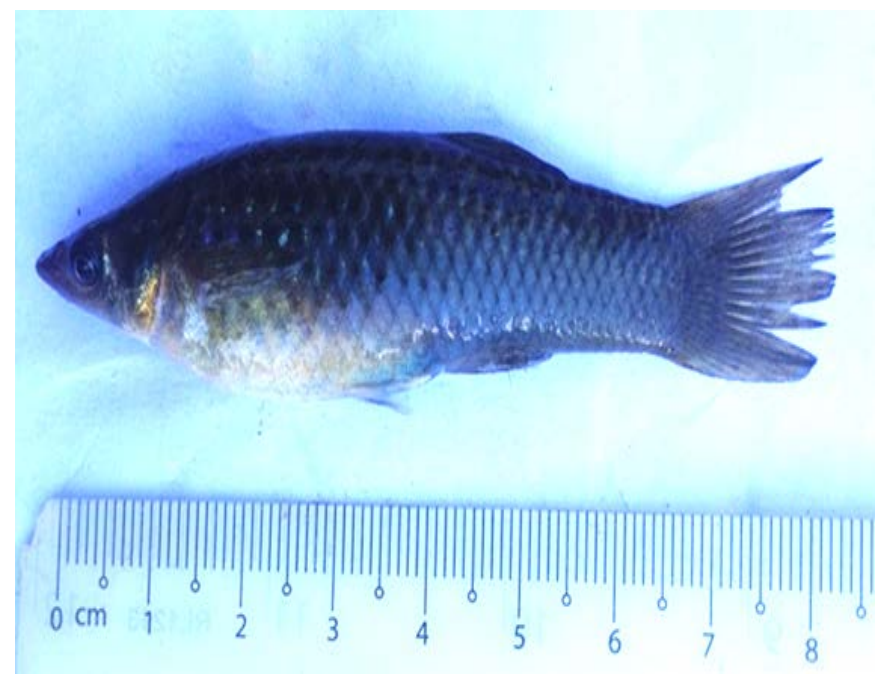

Figure 2. Gambussia affinis (Baird \& Girard, 1853).

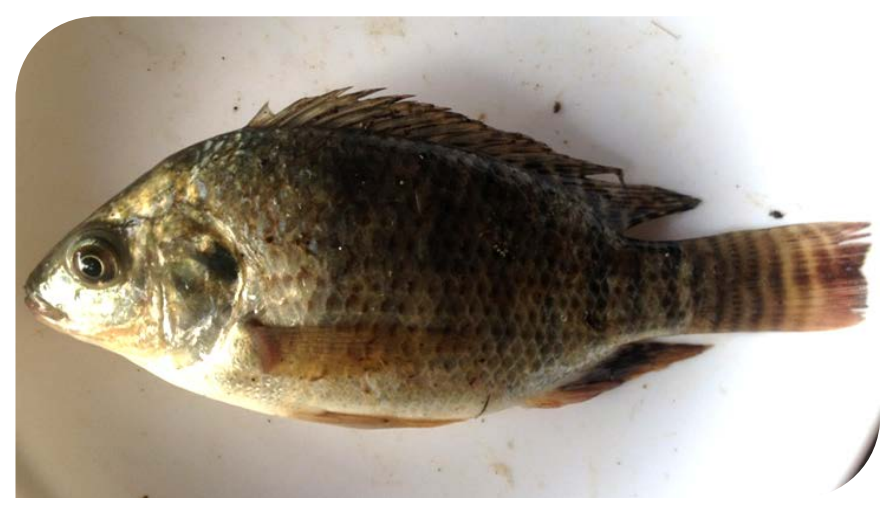

Figure 3. Oreochromis niloticus (Linnaeus, 1758).

\section{3) Anguilla bicolor (Figure 4)}

$\begin{array}{ll}\text { Kingdom: } & \text { Animalia } \\ \text { Phylum: } & \text { Chordata } \\ \text { Class: } & \text { Actinopterygii } \\ \text { Order: } & \text { Anguillilformes } \\ \text { Family: } & \text { Anguillidae } \\ \text { Genus: } & \text { Anguilla } \\ \text { Species: } & \text { bicolor } \\ \text { Common Name: } & \text { Shortfin Eel } \\ \text { Local Name: } & \text { Lutnak }\end{array}$

\section{Description:}

Dorsal spines (total): 0; Dorsal soft rays (total): 240 - 245; Anal spines: 0; Anal soft rays: 200 - 220; Vertebrae: 105 - 115. Olive to dark bluish-brown dorsally, lighter ventrally from jaw to anus. Dorsal body color uniform. Dorsal fin origin above vent. Teeth small, inconspicuous, multiserial, forming broad continuous bands on jaws and vomer; vomerine tooth-band extending as far back as bands of upper jaw but more pointed posteriorly (Froese and Pauly, 2014). 


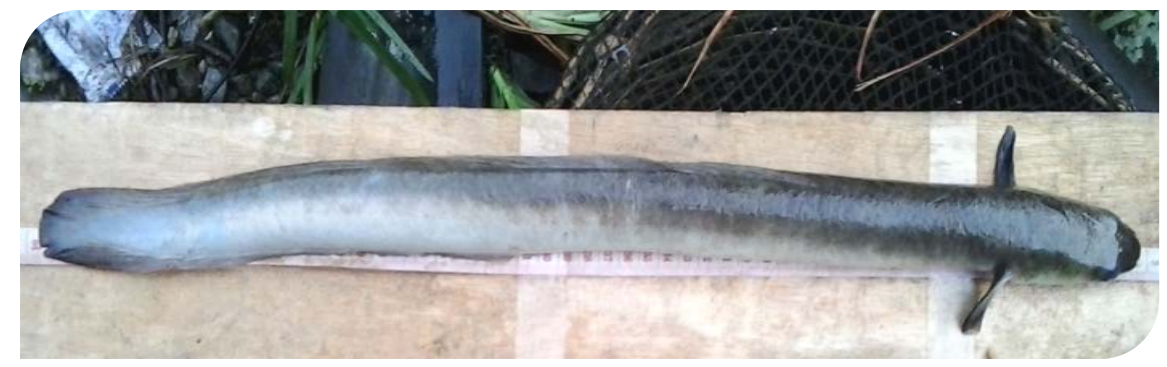

Figure 4. Anguilla bicolor (McClelland, 1844).

$\begin{array}{ll}\text { 4) Anguilla marmorata (Figure 5) } \\ \text { Kingdom: } & \text { Animalia } \\ \text { Phylum: } & \text { Chordata } \\ \text { Class: } & \text { Actinopterygii } \\ \text { Order: } & \text { Anguillilformes } \\ \text { Family: } & \text { Anguillidae } \\ \text { Genus: } & \text { Anguilla } \\ \text { Species: } & \text { marmorata } \\ \text { Common Name: } & \text { Giant Mottled Eel } \\ \text { Local Name: } & \text { Basangalan }\end{array}$

Description:

Vertebrae: 100 - 110. Max length: $200 \mathrm{~cm}$ (TL). Adults have a brownish to black marbling on their back on a greyish yellow background. This coloration can fade away. White belly. Younger specimens are greyish to orange and the marbling is less visible. Body color brown speckles scattered on back, sides and fins; yellow between speckles and edge of pectoral fin; belly white or pale blue. Head rounded; snout depressed; lower jaw protruded; gill openings small; scales matted-like under skin; pectoral fin rounded; pelvic fin absent. Distinguished from all other species by the mottled color and the long dorsal fin, which begins closer to the gill opening than to the anus (Froese and Pauly, 2014).

$\begin{array}{ll}\text { 5) Lentipes armatus } & \text { (Figure 6) } \\ \text { Kingdom: } & \text { Animalia } \\ \text { Phylum: } & \text { Chordata } \\ \text { Class: } & \text { Actinopterygii } \\ \text { Order: } & \text { Perciformes } \\ \text { Family: } & \text { Gobiidae } \\ \text { Genus: } & \text { Lentipes } \\ \text { Species: } & \text { armatus } \\ \text { Common Name: } & \text { Japanese Rainbow Goby } \\ \text { Local Name: } & \text { Dapil }\end{array}$

Description:

Dorsal soft rays (total): 10; Anal spines: 1; Anal soft rays: 10. Distinguished from other congeners by the following combinations of features: fin shape and rays counts: second dorsal fin rays I/10; anal fin rays I/10; pectoral fin rays 17 19; first dorsal fin with all rays about equal without filaments, and 3 - 4 rays 


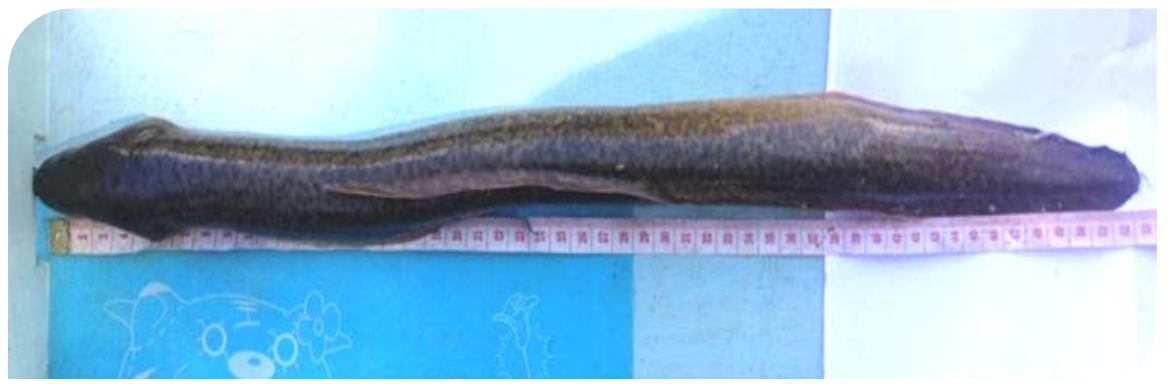

Figure 5. Anguilla marmorata (Quoy \& Gaimard, 1824).

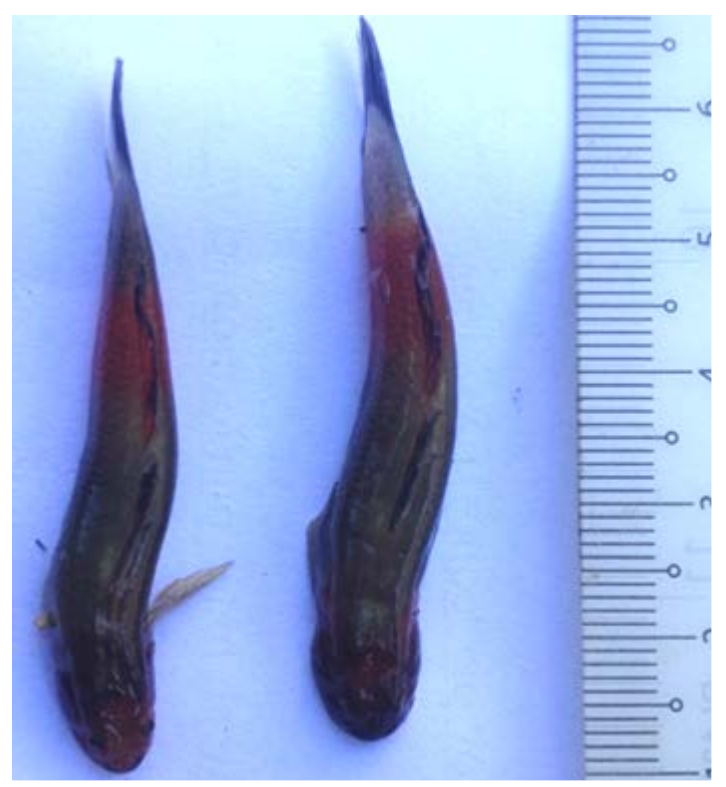

Figure 6. Lentipes armatus (Sakai \& Nakamura, 1979).

slightly longer in male; second dorsal fin with higher rays in anterior and posterior rays shorter; squamation: longitudinal scale series 35 - 38; predorsal region naked, body with median-size ctenoid scales; specific coloration pattern: a dark purple cross band below second dorsal fin base; female: dorsal half of lateral with irregularly dark brown bars and marks; male: belly greenish blue with three vertical brown stripes; second dorsal fin brownish with a diagnostic deep black spot between the first and second branched rays in male (Froese and Pauly, 2014).

6) Rhyacichthys aspro (Figure 7)

$\begin{array}{ll}\text { Kingdom: } & \text { Animalia } \\ \text { Phylum: } & \text { Chordata } \\ \text { Class: } & \text { Actinopterygii } \\ \text { Order: } & \text { Perciformes } \\ \text { Family: } & \text { Rhyacichthyidae } \\ \text { Genus: } & \text { Rhyacichthys } \\ \text { Species: } & \text { aspro } \\ \text { Common Name: } & \text { Loach Goby } \\ \text { Local Name: } & \text { Kampa }\end{array}$




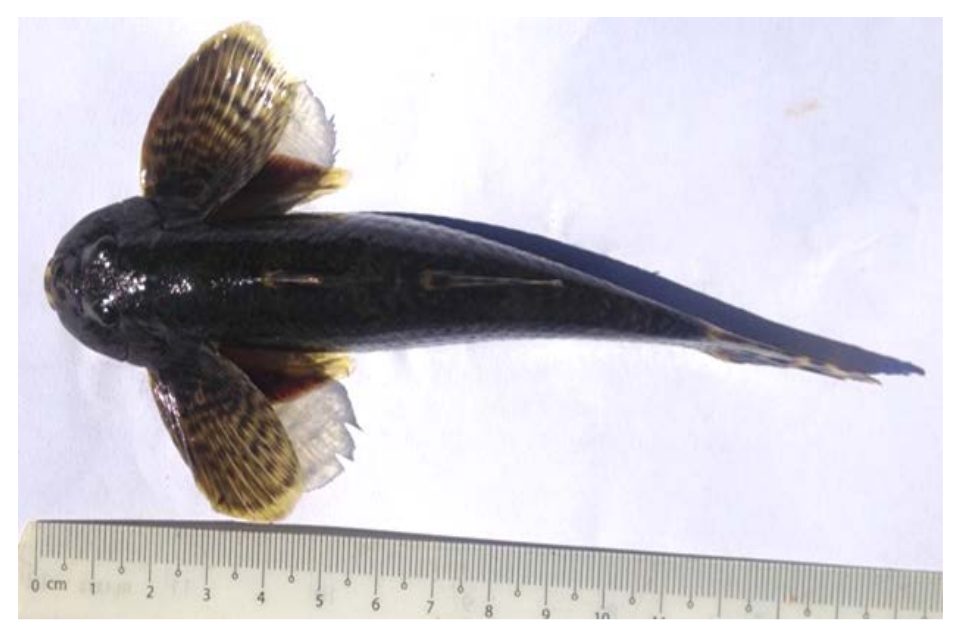

Figure 7. Rhyacichthys aspro (Valenciennes, 1837).

\section{Description:}

Dorsal spines (total): 8; Dorsal soft rays (total): 8 - 9; Anal spines: 1; Anal soft rays: 8 - 9. Characterized by having enlarged, thickened and wide pectoral fins; widely spaced broad fleshy pelvic fin; head and snout flattened, small dorsolaterally oriented eyes; small ventrally placed mouth; accessory lateral line canals dorsal and ventral to the lateral line on the body, including caudal fin base; caudal fin large (Froese and Pauly, 2014).

7) Glossogobius giuris (Figure 8)

$\begin{array}{ll}\text { Kingdom: } & \text { Animalia } \\ \text { Phylum: } & \text { Chordata } \\ \text { Class: } & \text { Actinopterygii } \\ \text { Order: } & \text { Perciformes } \\ \text { Family: } & \text { Gobiidae } \\ \text { Genus: } & \text { Glossogobius } \\ \text { Species: } & \text { giuris } \\ \text { Common Name: } & \text { Tank Goby } \\ \text { Local Name: } & \text { Bunog }\end{array}$

\section{Description:}

Dorsal spines (total): 7; Dorsal soft rays (total): 8 - 9; Anal spines: 1; Anal soft rays: 8 - 9. Head flattened, lower jaw projecting; body pale without longitudinal lines. Dorsal fins with small spots forming longitudinal stripes. Pelvic fins jointed but attached to the body only from their anterior part. The body is brownish yellow with 5 to 6 dark and rounded spots on its sides. Some specimens living on dark substrates can be very dark also. Some living on very light substrates show an ivory coloration. Dorsal fins are light with brownish spots. Pelvic fins are grey. Pectorals and caudal are grey and often hyaline [17].

\section{8) Sicyopterus lagocephalus (Figure 9)}
Kingdom
Animalia
Phylum
Chordata 


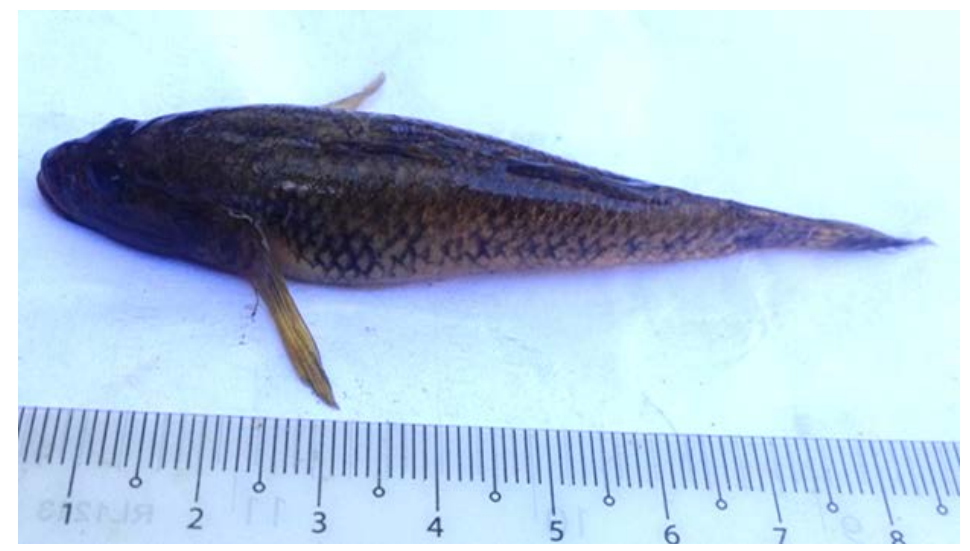

Figure 8. Glossogobius giuris (Hamilton, 1822).

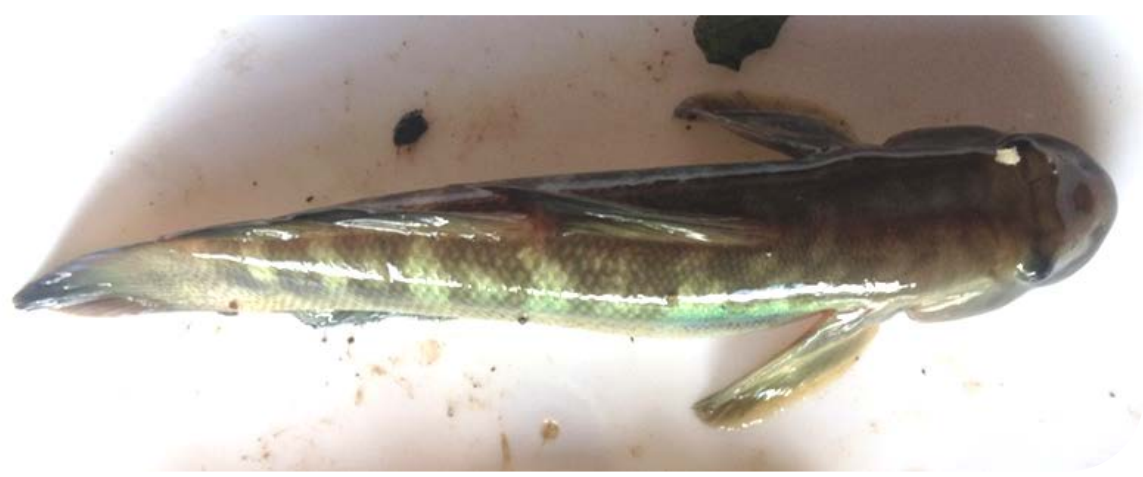

Figure 9. Sicyopterus lagocephalus (Pallas, 1770).

$\begin{array}{ll}\text { Class } & \text { Actinopterygii } \\ \text { Order } & \text { Perciformes } \\ \text { Family } & \text { Gobiidae } \\ \text { Genus } & \text { Sicyopterus } \\ \text { Species } & \text { lagocephalus } \\ \text { Common Name } & \text { Red-tailed Goby } \\ \text { Local Name } & \text { Tibek }\end{array}$

Description:

Body length: 24 to $120 \mathrm{~mm}$ SL. Females and males age range: 1 to 6 years. Males had larger asymptotic length. Eggs of $0.5 \mathrm{~mm}$ diameter attached to stones. Newly hatched larvae made continuous vertical movements of sinking and upward swimming-longer in freshwater than in seawater. Size of larvae: mean of $1.4 \mathrm{~mm}$ TL with a yolk sac and no eye pigmentation [18]. Two dorsal fins: $1^{\text {st }}$ dorsal fin has 6 rays while $2^{\text {nd }}$ dorsal fin has 11 rays. Third fin ray of the $1^{\text {st }}$ dorsal fin is elongated that forms like a hair-like structure extension. Anal fin has dark colored edge with 12 rays. Fused pelvic fins.

9) Rhinogobius sp. (Figure 10)

$\begin{array}{ll}\text { Kingdom: } & \text { Animalia } \\ \text { Phylum: } & \text { Chordata } \\ \text { Class. } & \text { Actinopterygii }\end{array}$




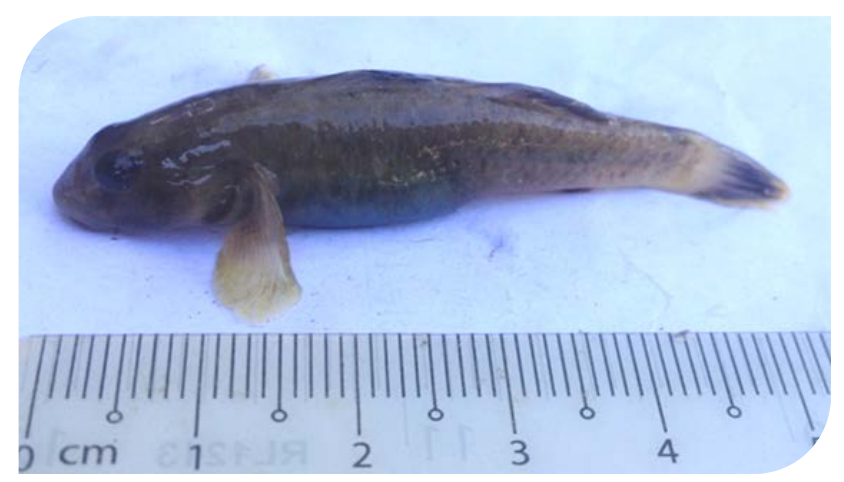

Figure 10. Rhinogobius sp.

\begin{tabular}{|c|c|}
\hline Order: & Perciformes \\
\hline Family: & Gobiidae \\
\hline Genus: & Rhinogobius \\
\hline \multicolumn{2}{|l|}{ Species: } \\
\hline Common Name: & Freshwater Goby \\
\hline Local Name: & Wadingan \\
\hline Description: & \\
\hline
\end{tabular}

Male size is larger than female. Largest size caught is $7 \mathrm{~cm}$. Male mouth is also larger than female. Color of male is darker than female from dark gray to brown with yellowish fins. Has two dorsal fins and fused pelvic fins. It has $6-71^{\text {st }}$ dorsal fin rays while $2^{\text {nd }}$ dorsal has 10 fin rays. Have 8 anal fin rays. Lower and upper sets of teeth present. Eyes are closely positioned dorso-anteriorly. Sex easily determined by genital papilla.

10) Macrobrachiumlepidactylus (Figure 11)

$\begin{array}{ll}\text { Kingdom: } & \text { Animalia } \\ \text { Phylum: } & \text { Arthropoda } \\ \text { Class: } & \text { Malacostraca } \\ \text { Order: } & \text { Decapoda } \\ \text { Family: } & \text { Palaemonidae } \\ \text { Genus: } & \text { Macrobrachium } \\ \text { Species: } & \text { lepidactylus } \\ \text { Common Name: } & \text { Madagascar Scale Prawn } \\ \text { Local Name: } & \text { Udang } \\ \text { Description: } & \end{array}$

Distinguishing characteristic is its big chelipeds-different compared to the giant freshwater prawn (M. rosenbergii). One cheliped is bigger than the other either left or right. Bigger cheliped has a saw-like clip. Smaller cheliped has a hairy brush-like clip. It is believed that both are used in different purposes but still undocumented. Rostrum has 12 teeth pointed diagonally upward. Percentage of rostrum is more than its extension. Has 3 pairs of walking legs, 5 pairs of swimming legs and another pair of smaller pincers before the big ones. Two other appendages are located before the smaller chelipeds. 


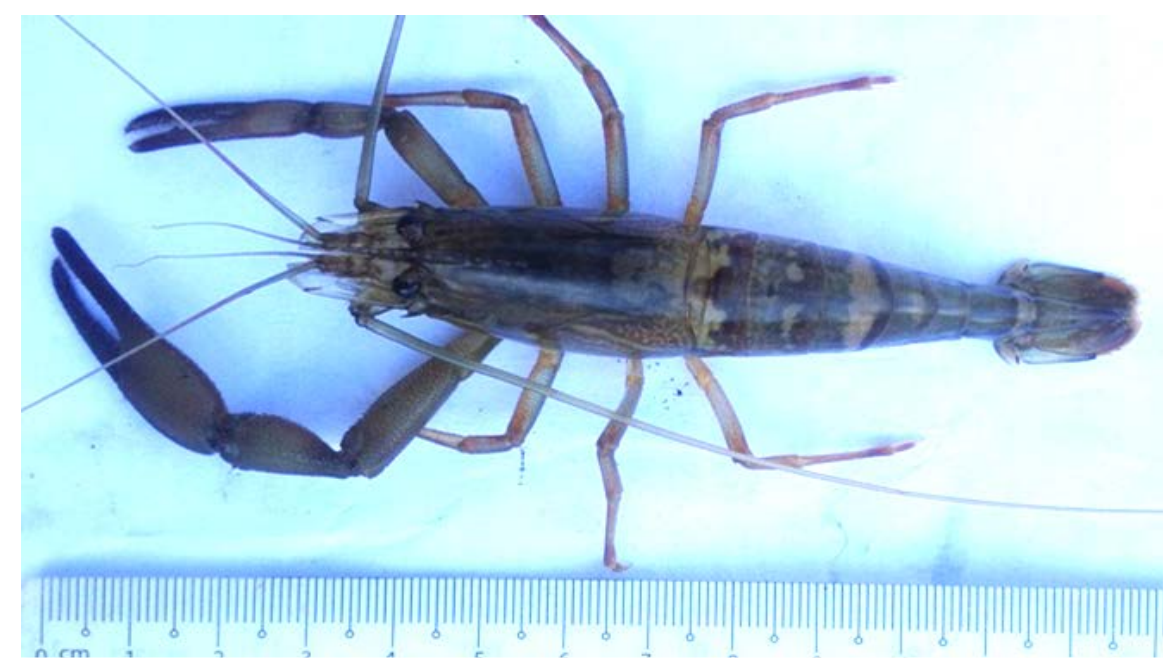

Figure 11. Macrobrachiumlepidactylus (Hilgendorf, 1879).

$\begin{array}{ll}\text { 11) Atyopsis moluccensis (Figure 12) } \\ \text { Kingdom: } & \text { Animalia } \\ \text { Phylum: } & \text { Arthropoda } \\ \text { Class. } & \text { Malacostraca } \\ \text { Order: } & \text { Decapoda } \\ \text { Family: } & \text { Atyidae } \\ \text { Genus: } & \text { Atyopsis } \\ \text { Species: } & \text { moluccensis } \\ \text { Common Name: } & \text { Wood Shrimp } \\ \text { Local Name: } & \text { Kinod }\end{array}$

Description:

Prawn belonging to the genus Atyopsis, with a short rostrum and a background coloration going from orange to tan. The first and second set of periopods (walking legs) is equipped with hairs that the shrimp can open like a fan to filter micro-particles floating in the water. The third pair of periopods is very developed but does not bear claws. A line goes through the body from the rostrum to the telson. Species that favors strong currents in its habitat.

12) Macrobrachium sp. (Figure 13)

$\begin{array}{ll}\text { Kingdom: } & \text { Animalia } \\ \text { Phylum: } & \text { Arthropoda } \\ \text { Class: } & \text { Malacostraca } \\ \text { Order: } & \text { Decapoda } \\ \text { Family: } & \text { Palaemonidae } \\ \text { Genus: } & \text { Macrobrachium }\end{array}$

Species:

Common Name: Freshwater Prawn

Local Name: $\quad$ Tangad

Description:

Has a defined large pincers but smaller than the Madagascar Scale Prawn. 


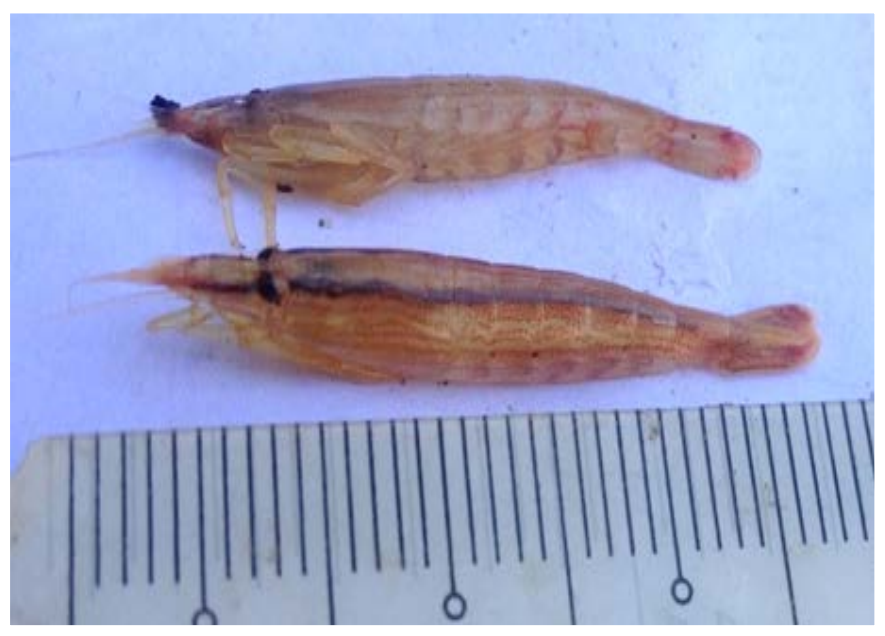

Figure 12. Atyopsis moluccensis (De Haan, 1849).

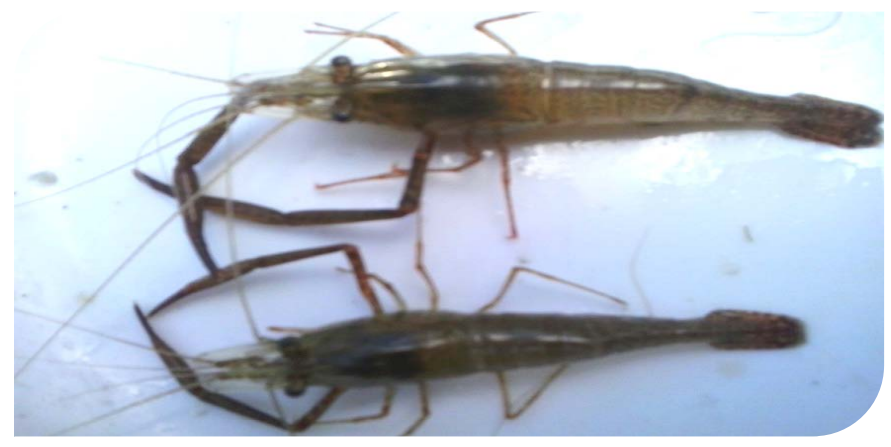

Figure 13. Macrobrachium sp.

Male are distinguished to female with its larger pincers. Male body are larger than female at $7 \mathrm{~cm}$ and $4 \mathrm{~cm}$, respectively. Has a transparent exoskeleton with dark brown spots and marking on the body.

13) Sundathelphusa sp. (Figure 14)

$\begin{array}{ll}\text { Kingdom: } & \text { Animalia } \\ \text { Phylum: } & \text { Arthropoda } \\ \text { Class: } & \text { Malacostraca } \\ \text { Order: } & \text { Decapoda } \\ \text { Family: } & \text { Gecarcinucidae } \\ \text { Genus: } & \text { Sundathelphusa }\end{array}$

Species.

Common Name: $\quad$ Freshwater Crab

Local Name: $\quad$ Gakki

Description:

Male are larger than female. Largest caught in Amburayan River is $3.5 \mathrm{~cm}$ carapace length. Male has different size of cheliped while female has the same size. Color varies from dark brown to black but chelipeds are orange to dark brown.

14) Melanoides maculata (Figure 15)

Kingdom:

Animalia 


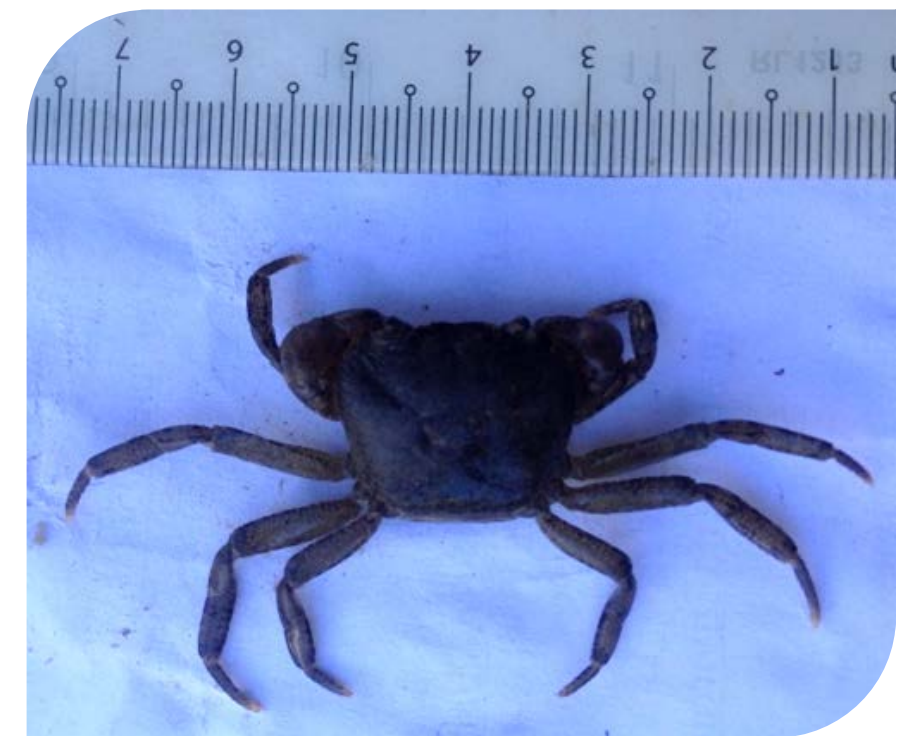

Figure 14. Sundathelphusa sp.

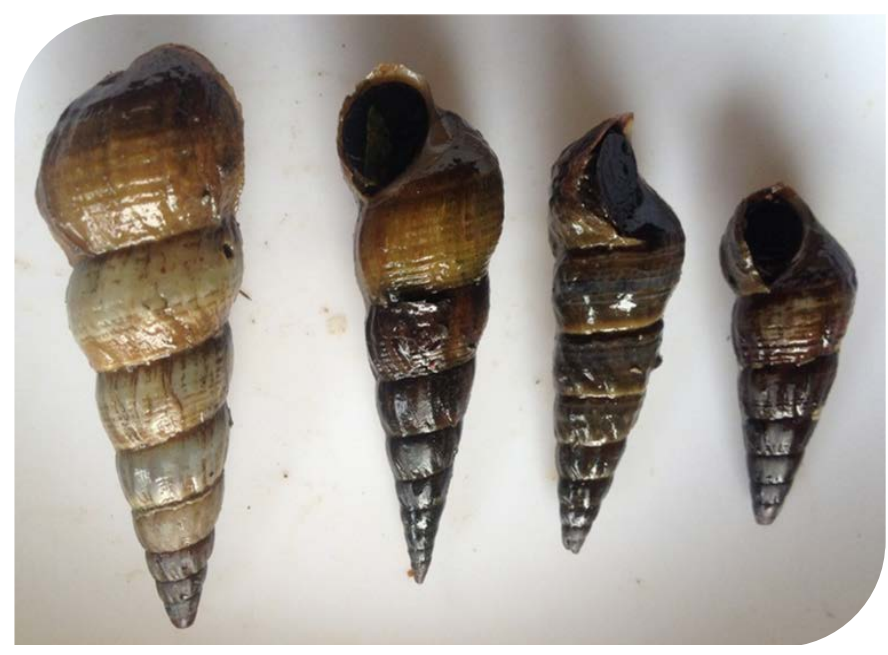

Figure 15. Melanoides maculata (Born, 1780).

$\begin{array}{ll}\text { Phylum: } & \text { Mollusca } \\ \text { Class: } & \text { Gastropoda } \\ \text { Order: } & \text { Sorbeochoncha } \\ \text { Family: } & \text { Thiaridae } \\ \text { Genus: } & \text { Melanoides } \\ \text { Species: } & \text { maculata } \\ \text { Common Name: } & \text { Mahogany Trumpet Snail } \\ \text { Local Name: } & \text { Agudung } \\ \text { Description: } & \end{array}$

Golden brown to dark mahogany brown in color depending on the environment of its habitat. Has 6 - 9 whirls depending on the size and has an operculum cover. Elongated shell and has high concave spires and rounded aperture. Sinistral spin of shell. 


\subsection{Ecological Parameters}

There were 5216 individuals collected in the five stations of the research area (Table 4). Most of the species that comprise the catch are Rhinogobius sp. or "wadingan" (34.24\%), M. lepidactylus or "udang" (31.78\%) and Sundathelphusa $s p$. or "gakki" (30.48\%). The other 11 species only make up the $3.49 \%$ of the total catch. "Wadingan" produced the highest number of individuals because these species of goby are small. As observed during the sampling, "wadingan" with an average length of about two to three centimeters were already berried. This means that they mature easily and reproduce at short period of time. In this way, the stock population of "wadingan" can easily recover.

In terms of Relative Frequency (RF), "gakki" gained the highest followed by "udang" and "wadingan" at values of $23.67 \%, 23.19 \%$ and $21.26 \%$, respectively (Table 4). In this parameter, "gakki" gives the highest value because it can migrate both in riverside and in water column. "Gakki" could also be caught not only in shallow areas but also in medium deep water level of the river with the fyke nets. This behavior of "gakki" supports the value of ecosystem's relative

Table 4. Ecological parameters of the surveyed and identified macro aquatic species in Amburayan River in Kapangan, Benguet.

\begin{tabular}{|c|c|c|c|c|c|c|c|c|c|c|}
\hline $\begin{array}{l}\text { COMMON } \\
\text { NAME }\end{array}$ & LOCAL NAME & SCIENTIFIC NAME & $\begin{array}{c}\text { NO. OF } \\
\text { IND. }\end{array}$ & $\mathbf{F}$ & RF (\%) & $\mathrm{D}$ & RD (\%) & Do & RDo (\%) & IVI (\%) \\
\hline \multicolumn{11}{|l|}{ Fish (9) } \\
\hline Goby & Wadingan & Rhinogobius sp. & 1786 & 0.587 & 21.256 & 0.198 & 34.241 & 0.117 & 37.652 & 93.149 \\
\hline Giant Mottled Eel & Basangalan & Anguilla marmorata & 33 & 0.307 & 11.111 & 0.004 & 0.633 & 0.000 & 0.013 & 11.757 \\
\hline Shortfin Eel & Lutnak & Anguilla bicolor & 1 & 0.013 & 0.483 & 0.000 & 0.019 & 0.000 & 0.000 & 0.502 \\
\hline Red-tailed Goby & Tibek & Sicyopterus lagocephalus & 15 & 0.040 & 1.449 & 0.002 & 0.288 & 0.000 & 0.003 & 1.740 \\
\hline Loach Goby & Kampa & Rhyacichthys aspro & 40 & 0.227 & 8.213 & 0.004 & 0.767 & 0.000 & 0.019 & 8.998 \\
\hline Nile Tilapia & Tilapia & Oreochromis niloticus & 5 & 0.027 & 0.966 & 0.001 & 0.096 & 0.000 & 0.000 & 1.062 \\
\hline Mosquito Fish & Tamtampi & Gambussia affinis & 30 & 0.120 & 4.348 & 0.003 & 0.575 & 0.000 & 0.011 & 4.934 \\
\hline $\begin{array}{c}\text { Japanese Rainbow } \\
\text { Goby }\end{array}$ & Dapil & Lentipes armatus & 18 & 0.027 & 0.966 & 0.002 & 0.345 & 0.000 & 0.004 & 1.315 \\
\hline Tank Goby & Bunog & Glossogobius giuris & 24 & 0.027 & 0.966 & 0.003 & 0.460 & 0.000 & 0.007 & 1.433 \\
\hline \multicolumn{11}{|l|}{ Crustacean (4) } \\
\hline $\begin{array}{c}\text { Madagascar Scale } \\
\text { Prawn }\end{array}$ & Udang & Macrobrachiumlepidactylus & 1658 & 0.640 & 23.188 & 0.184 & 31.787 & 0.101 & 32.449 & 87.424 \\
\hline Wood Shrimp & Kinod & Atyopsismuloccensis & 13 & 0.053 & 1.932 & 0.001 & 0.249 & 0.000 & 0.002 & 2.184 \\
\hline Freshwater Prawn & Tangad & Macrobrachium sp. & 2 & 0.027 & 0.966 & 0.000 & 0.038 & 0.000 & 0.000 & 1.005 \\
\hline Freshwater Crab & Gakki & Sundathelphusa sp. & 1590 & 0.653 & 23.671 & 0.177 & 30.483 & 0.093 & 29.841 & 83.996 \\
\hline \multicolumn{11}{|l|}{ Gastropod (1) } \\
\hline $\begin{array}{c}\text { Mahogany } \\
\text { Trumpet Snail }\end{array}$ & Agudong & Melanoides maculata & 1 & 0.013 & 0.483 & 0.000 & 0.019 & 0.000 & 0.000 & 0.502 \\
\hline TOTAL & & & 5216 & 2.76 & 100 & 0.58 & 100 & 0.31 & 100 & 300 \\
\hline
\end{tabular}

Species Diversity/Shannon Diversity Index = 1.2815. Legend: F-Frequency; D—Density; Do-Dominance; IVI-Importance; RF-Relative Frequency; RD-Relative Density; RDo-Relative Dominance; Value Index. 
frequency. In addition, "gakki" feeds on the small fish species such as "wadingan", bunog" and "dapil" They also prey some of the prawn species caught by the fyke nets and fish pots which serves as bait for them. These reasons made them to be caught in more than $65 \%$ of the total number of quadrats in the study which attributed them to gain the highest value of RF.

The Importance Value Impact (IVI) of the species are calculated as the sum of the Relative Frequency (RF), Relative Density (RD) and Relative Dominance (RDo).Summing up the values of RF, RD and RDo, the three mentioned species have the highest Importance Value Index (IVI) of 93.15\%, 87.42\% and $84.00 \%$ for "wadingan", "udang" and "gakki", respectively. The result of the Species Diversity Index (SDI) for the 14 species with 5216 individuals is 1.28 which means that the Amburayan River has a very low diversity (Table 4). The "udang" was always on the second position because the same as the "gakki", they can move from the shore to the deeper water areas. They are also attracted by the "wadingan" and "dapil" that were caught by the fyke nets. "Udang" also feeds on this species. It was noted that fyke nets were the most fishing gears used in the collection of samples. With this, multi-species are caught both set in shallow and deeper water areas of the river.

The other species such as "lutnak", "basangalan", "tibek" and "kampa" gained small values of the RF, $\mathrm{RD}$ and $\mathrm{RDo}$ because rainy season is the peak periods for them to be caught when the stocks from the upstream tributaries are drained as the river's water level increases. Tilapia and "bunog" according to the fishermen has only little population in the area and this is supported by the data gathered. The mosquito fish has just started to proliferate again since their young were observed along the shallow areas of the river together with the fingerlings of other goby species. The only gastropod that was caught was incidental since this species usually inhabit the smaller tributaries of the river.

\subsection{Catch Composition}

In terms of weight, "gakki" has the highest volume of catch at $12.083 \mathrm{~kg}$ followed by "basangalan" and "wadingan" with values of $9.061 \mathrm{~kg}$ and $5.120 \mathrm{~kg}$, respectively as shown in Figure 16. The high population of "gakki" with higher weight compared to "wadingan" surpassed the total biomass contribution of the latter from the total catch. This case is also the same with bigger size species such as the "basangalan". Though, there were only few quantities that were caught because the peak season of this species is during the rainy months of the year.

The population of the macro aquatic organisms in Amburayan River is significant in the species-specific or in multi-species management. That is why the ecological parameters of the surveyed and identified species were recorded and analyzed. However, it is also important to determine not only the individual count of the present stocks but also the biomass which contribute to the river ecosystem. One of the reasons is that there is a certain biomass that each and every ecosystem could cater and it is called the biological carrying capacity. This 


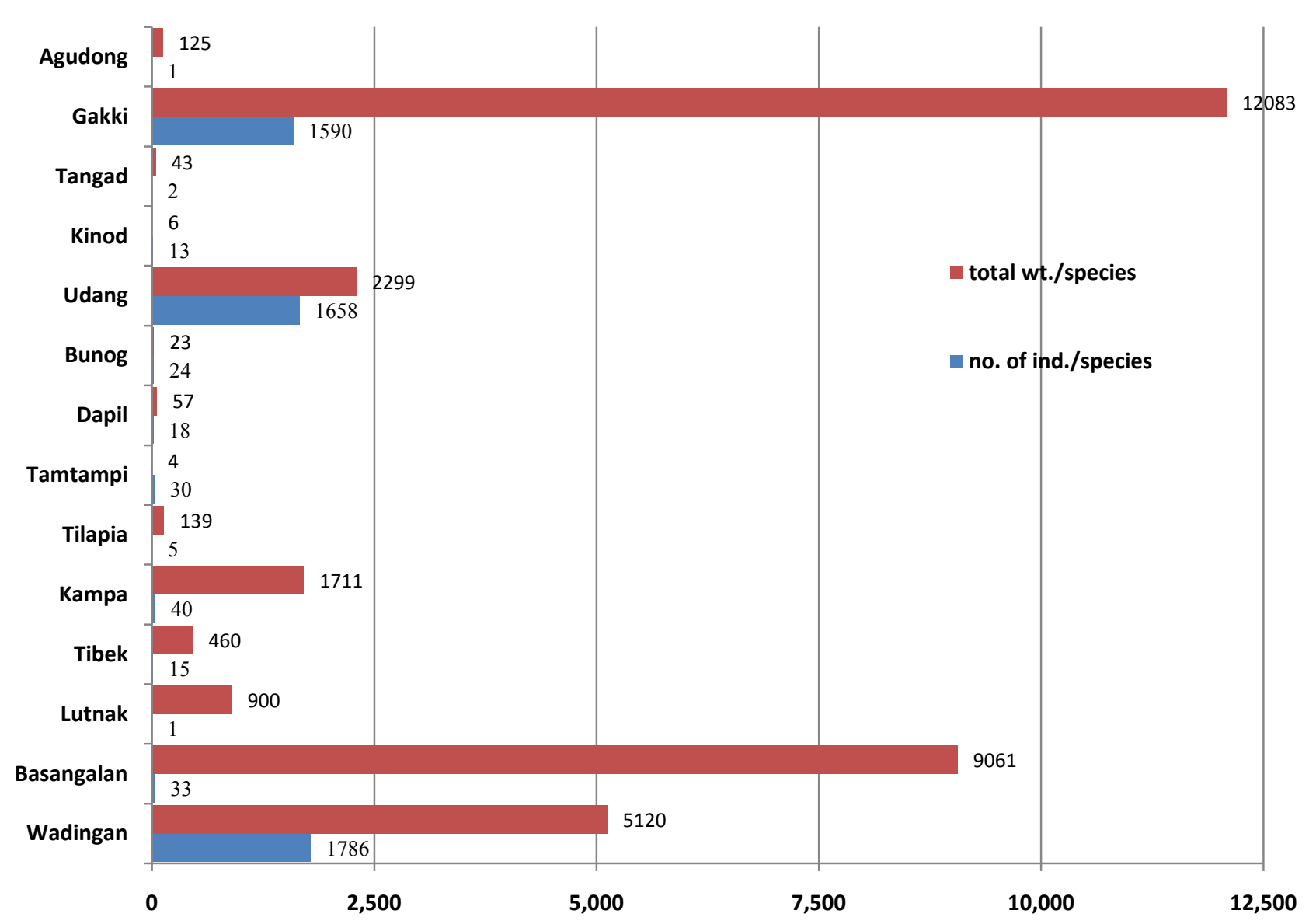

Figure 16. Catch composition of macro aquatic organisms in Amburayan River in Kapangan, Benguet in terms of individual count (pcs) and total weight (g).

is important in understanding the complex relationship of the ecosystem such as the food chain.

Analyzing the data, the population of individual species does not mean the same with the biomass of each and every species caught and identified. They have different contribution and effects to the ecosystem. There are certain species such as the large ones that have high biomass per individual. These species should be put into the priority management because a decrease or increase of their number greatly affects the biomass of the ecosystem.

If to compare the biomass contributions of bigger species with the small ones such as "wadingan" with an average weight of $3 \mathrm{~g}$, reduction or reproduction of 1000 individuals will only remove or recruit $3 \mathrm{~kg}$ of biomass from and to the ecosystem, respectively. There is only a little pressure on this compared to the recruitment or fishing of large species such as "basangalan". With an average weight of $394 \mathrm{~g} /$ individual, 1000 pieces of catch will mean a value of $394 \mathrm{~kg}$ that will be removed from the ecosystem. Loss of this biomass in the ecosystem will result to system imbalance.

It is also noted that the smaller species reproduce faster compared to the large ones. In order to balance the ecosystem, catching of every species should be con- 
trolled and regulated according to the ecological need of the ecosystem generated from the assessment activities.

Figure 17 shows that "wadingan" (34.24\%), "udang" (31.79\%) and "gakki" (30.48\%) comprise the highest number of individuals from the conducted study. The alarming proliferation of "gakki" is threatening the populations of smaller stocks such as "wadingan", "bunog”, "dapil and other prawn species available in the ecosystem.

This scenario shows the unbalance biodiversity of the Amburayan River. Eel species such as the "lutnak" and "basangalan" that feeds on the "gakki" have already limited populations. These species are potential biological control entities of the increasing "gakki" population in the ecosystem.

"Udang" which also feeds on the small macro aquatic species has high population. With this, "udang" also serves as an additional threat to the biomass of small fish species in the river ecosystem.

The catch composition of the caught macro aquatic species present in Amburayan River in Kapangan, Benguet with respect to biomass is shown in Figure 17. It is observed that "gakki", "basangalan", and "wadingan" gives the highest values of $37.72 \%, 28.29 \%$ and $15.98 \%$, respectively.

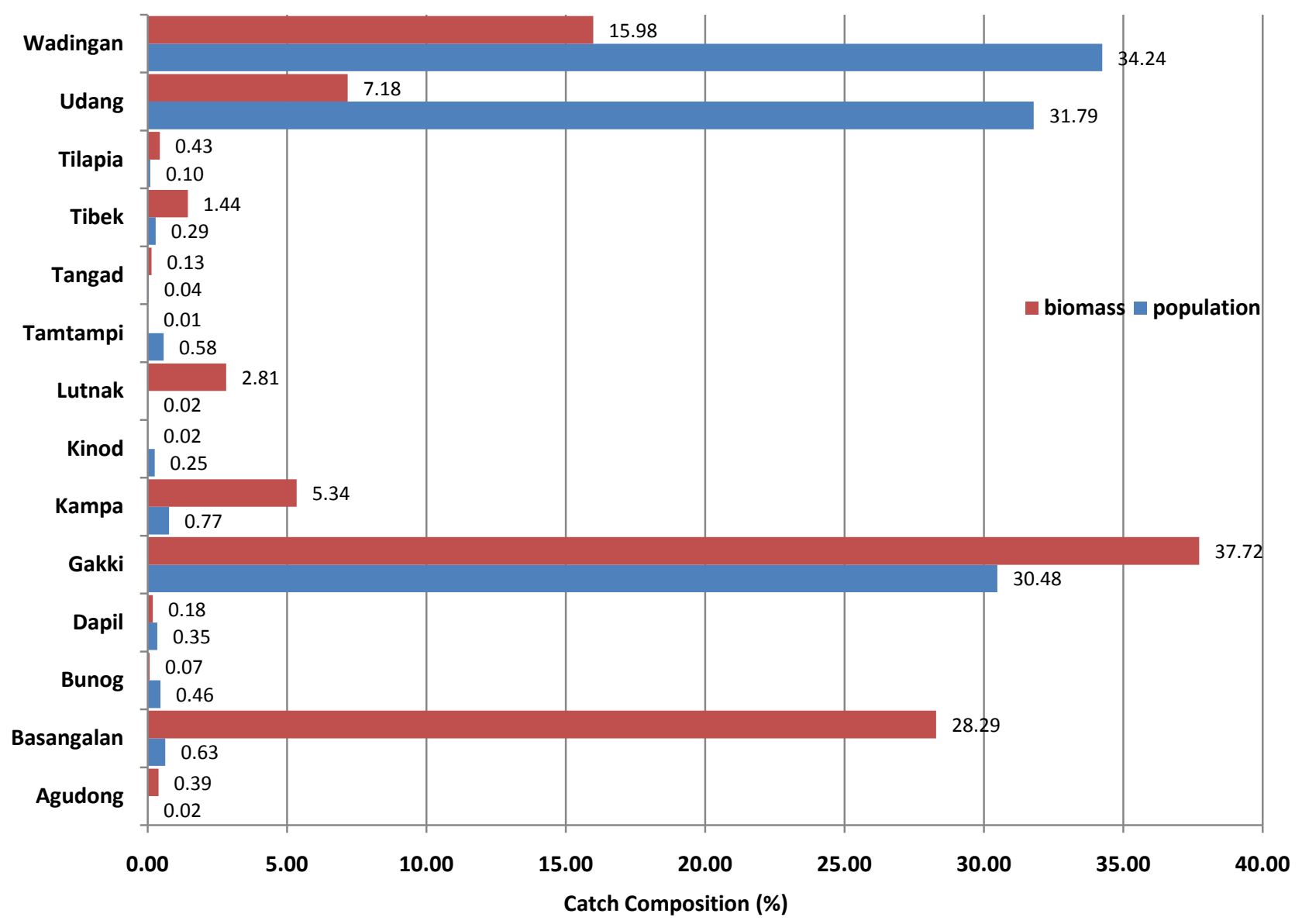

Figure 17. Comparison of population and biomass of the available macro aquatic species in Amburayan River in Kapagan, Benguet. 
This statistical data shows that despite the population of each and every stocks present in the river, there are other factors that affect the ecological balance such as the biomass or weight of total stocks' population of the macro aquatic species. It is observed that "gakki" has the highest biomass. Considering the principles of the ecosystem, the organisms that belong to the top level of the food web or the producers and primary consumers should have higher biomass than the organisms under the lower levels.

The result of the study shows that the small macro aquatic species available in the Amburayan which serve as prey for the lower level consumers have lower biomass than its predators. With this, it is significant to check on the population of "gakki". "Basangalan" which is ranked second may have sustainable population to control the "gakki". However, it is also noted that "basangalan" feeds on other smaller stocks and compete with the "gakki". In this way, "basangalan's" biomass cannot totally control the proliferation of "gakki" in the ecosystem.

Comparison of the catch composition in terms of biomass and population of macro aquatic species present in Amburayan River in Kapangan, Benguet is also illustrated in Figure 17. This shows that population and biomass are good factors to consider in species-specific and multi-species management of the river ecosystem.

\subsection{Indigenous Species}

The result of the FGD shows that there are indigenous and introduced species caught in the river aside from the collected samples. These are common carp (Cyprinus carpio), African catfish (Clarias gariepinus), Japanese weather loach (Misgurnus anguillicaudatus) and freshwater prawn species (Macrobrachium sp.) This is because the biodiversity of macro aquatic species in the river are also seasonal which means that there are species that are caught during the rainy season but absent during the summer months and vice versa. However, there are also species that are present in both seasons but are in different size. Some of the indigenous species were gone and substituted by new species. These were locally called as "bagsang" and "ludong" (both are mullet species) and another species of freshwater crab that was different from "gakki". Their disappearance was caused by the collapsed of dam site of mine tailings by the Western Minolco Mines/Boneng Mines collapsed in 1982. The incident did not only degrade the ecosystem but also caused mortality of some members of the community.

Table 5 shows the indigenous and introduced macro aquatic species caught in Amburayan River for the season that falls in the months of December 2014 and January 2015. It is observed that common carp and catfish were not caught during these months even if there were already reports from the fishermen that these species already inhabited the Amburayan River.

The "lutnak" and "basangalan" are highly migratory species which inhabit freshwater, brackish water and marine environments. These species lives in brackish and marine as young, in freshwater as adults, and descend to the sea to 
Table 5. Indigenous and introduced macro aquatic species in Amburayan River, Kapangan, Benguet.

\begin{tabular}{|c|c|c|c|c|c|}
\hline COMMON NAME & $\begin{array}{l}\text { LOCAL } \\
\text { NAME }\end{array}$ & SCIENTIFIC NAME & FEEDING HABIT & $\begin{array}{l}\text { RANGE OF } \\
\text { HABITAT }\end{array}$ & REMARKS \\
\hline \multicolumn{6}{|l|}{ Fish (9) } \\
\hline Freshwater Goby & Wadingan & Rhinogobius sp. & $\begin{array}{c}\text { Feeds on small invertebrates } \\
\text { and phytoplanktons }\end{array}$ & Freshwater & Indigenous \\
\hline Giant Mottled Eel & Basangalan & Anguilla marmorata & $\begin{array}{l}\text { Feeds on a wide range of } \\
\text { prey, especially crabs, } \\
\text { frogs and fish }\end{array}$ & $\begin{array}{l}\text { Marine; brackish; } \\
\text { freshwater }\end{array}$ & Indigenous \\
\hline Shortfin Eel & Lutnak & Anguilla bicolor & $\begin{array}{l}\text { Feeds on small fishes, } \\
\text { crustaceans and mollusks. }\end{array}$ & $\begin{array}{l}\text { Marine; brackish; } \\
\text { freshwater }\end{array}$ & Indigenous \\
\hline Red-tailed Goby & Tibek & Sicyopterus lagocephalus & Feeds on adhesive algae & $\begin{array}{l}\text { Marine; brackish; } \\
\text { freshwater }\end{array}$ & Indigenous \\
\hline Loach Goby & Kampa & Rhyacichthys aspro & Feeds on algae and diatoms & $\begin{array}{l}\text { Marine; brackish; } \\
\text { freshwater }\end{array}$ & Indigenous \\
\hline Nile Tilapia & Tilapia & Oreochromis niloticus & $\begin{array}{l}\text { Feeds mainly on } \\
\text { phytoplankton or } \\
\text { benthic algae }\end{array}$ & $\begin{array}{l}\text { Marine; brackish; } \\
\text { freshwater }\end{array}$ & Introduced \\
\hline Mosquito Fish & Tamtampi & Gambussia affinis & $\begin{array}{l}\text { Feeds on zooplankton, small } \\
\text { insects and detritus }\end{array}$ & $\begin{array}{l}\text { Freshwater; } \\
\text { brackish }\end{array}$ & Introduced \\
\hline $\begin{array}{c}\text { Japanese Rainbow } \\
\text { Goby }\end{array}$ & Dapil & Lentipes armatus & $\begin{array}{c}\text { Feeds on small invertebrates } \\
\text { and planktons }\end{array}$ & $\begin{array}{l}\text { Marine; brackish; } \\
\text { freshwater }\end{array}$ & Indigenous \\
\hline Tank Goby & Bunog & Glossogobius giuris & $\begin{array}{l}\text { Feeds on small insects, } \\
\text { crustaceans and small fish }\end{array}$ & $\begin{array}{l}\text { Marine; brackish; } \\
\text { freshwater }\end{array}$ & Indigenous \\
\hline \multicolumn{6}{|l|}{ Crustacean (4) } \\
\hline $\begin{array}{l}\text { Madagascar Scale } \\
\text { Prawn }\end{array}$ & Udang & Macrobrachiumlepidactylus & $\begin{array}{l}\text { Consume algae, planktonic } \\
\text { organisms, small muscle } \\
\text { pieces of their own kind or } \\
\text { fish etc. }\end{array}$ & $\begin{array}{l}\text { Freshwater; } \\
\text { brackish }\end{array}$ & Indigenous \\
\hline Wood Shrimp & Kinod & Atyopsis moluccensis & $\begin{array}{l}\text { Consume algae, planktonic } \\
\text { organisms, small muscle } \\
\text { pieces of their own kind or } \\
\text { fish etc. }\end{array}$ & $\begin{array}{l}\text { Freshwater; } \\
\text { brackish }\end{array}$ & Indigenous \\
\hline Freshwater Prawn & Tangad & Macrobrachium sp. & $\begin{array}{c}\text { Consume algae, planktonic } \\
\text { organisms, small muscle } \\
\text { pieces of their own kind or } \\
\text { fish etc. }\end{array}$ & $\begin{array}{l}\text { Freshwater; } \\
\text { brackish }\end{array}$ & Indigenous \\
\hline Freshwater Crab & Gakki & Sundathelphusa sp. & $\begin{array}{c}\text { Omnivorous scavengers } \\
\text { but some are opportunistic } \\
\text { carnivores }\end{array}$ & Freshwater & Indigenous \\
\hline \multicolumn{6}{|l|}{ Gastropod (1) } \\
\hline $\begin{array}{l}\text { Mahogany } \\
\text { Trumpet Shell }\end{array}$ & Agudong & Melanoides maculate & Detritus feeders & Freshwater & Indigenous \\
\hline
\end{tabular}

spawn. According to Castle (1984), "basangalan" feeds on wide range of prey such as crabs, frogs and fish, while "lutnak" feeds on small fishes, crustaceans and mollusks [19]. "Dapil” and Rinogobius sp. are small fish species belonging 
to Family Gobiidae. They feed on small invertebrates and phytoplanktons (Wikipedia, 2015). "Dapil" inhabits freshwater, brackish water and marine environment [20] while Rhinogobius sp. are primarily freshwater gobies native to tropical and temperate parts of East Asia (Wikipedia, 2014) .

"Kampa" and "tibek" are gobies that belong to the Family Rhyacichthyidae and Gobiidae, respectively. These species feeds on algae and diatoms and inhabits marine, brackish water and freshwater environments. On the other hand, "bunog" which is also a goby species feeds on small insects, crustaceans and small fish. It inhabits freshwater, brackish water and marine ecosystems.

Sharma and Subba (2005) cited that prawn belonging to the Family Paleomonidae has marine origin and has acquired freshwater habitat by immigration from the sea to the interior of land through rivers. The prawn species such as "udang" "kinod" and "tangad" eat all types of food living or dead: consume algae, planktonic organisms, small muscle pieces of their own kind or fish [21].

The "gakki" is an omnivorous freshwater crab [22] (Nakhodai et al., 2013) and also an opportunistic carnivore [23] while the "agudung" is a detritus feeding freshwater gastropod.

\subsection{Introduced or Exotic Species}

The presence of introduced or exotic species in the area is caused by the introduction of mosquito fish as biological control of mosquito larvae in the mitigation of diseases carried by this insect (Table 4). On the other hand, tilapia was introduced as culture stock for aquaculture activities. Unfortunately, some of the introduced species escaped from their stocking ground or culture environments. Mosquito fish should be found in stagnant water areas near and/or within the backyard of every community. This is to prey on the larvae of mosquito that hatched in the stagnant waters to reduce the population of mosquito that transmits and carries the disease from one organism to the other. Hence, mitigate the spread of related disease. On the other hand, tilapia should also be in ponds where they are cultured as food for the local people.

According to [24], mosquito fish feeds on zooplanktons, insects and detritus. This made it potential as biological control of mosquito larvae, however, it is also a potential pest to the open water systems. It usually inhabits in standing to slow-flowing water and can tolerate brackish water environment. Tilapia on the other hand is phytoplankton or benthic algae feeders and inhabits freshwater to brackish water environments.

\subsection{Impact of Environmental Degradation in Aquatic Ecosystem of Amburayan River in Kapangan, Benguet}

It was found out that there were no moderate and major impacts on the environment among the listed sources of environmental degradation. However, small impacts are already experienced on the entire river ecosystem in general caused by pollution, soil erosion, sedimentation, dynamite fishing and inorganic fertilizer run-off hazard (Table 6). 
Table 6. Sources of small impact from the threats caused by anthropogenic activities and environmental disturbances to the Amburayan River in Kapangan, Benguet.

\begin{tabular}{|c|c|c|c|c|c|c|c|c|c|c|}
\hline \multirow{3}{*}{$\begin{array}{l}\text { DAMAGE TO } \\
\text { ENVIRONMENT }\end{array}$} & \multicolumn{9}{|c|}{ SOURCES OF ENVIRONMENTAL DEGRADATION } & \multirow[b]{3}{*}{ REMARKS } \\
\hline & \multicolumn{5}{|c|}{ Pollution } & \multirow[b]{2}{*}{$\begin{array}{c}\text { Soil } \\
\text { Erosion }\end{array}$} & \multirow[b]{2}{*}{ Sedimentation } & \multirow[b]{2}{*}{$\begin{array}{l}\text { Dynamite } \\
\text { Fishing }\end{array}$} & \multirow[b]{2}{*}{$\begin{array}{c}\text { Inorganic } \\
\text { Fertilizer } \\
\text { Run-off } \\
\text { Hazard }\end{array}$} & \\
\hline & $\begin{array}{c}\text { Solid } \\
\text { wastes }\end{array}$ & $\begin{array}{c}\text { Oil } \\
\text { spill }\end{array}$ & $\begin{array}{l}\text { Toxic } \\
\text { chemical } \\
\text { hazard }\end{array}$ & $\begin{array}{l}\text { Mine } \\
\text { tailings }\end{array}$ & $\begin{array}{l}\text { Mine } \\
\text { drainage } \\
\text { pollution }\end{array}$ & & & & & \\
\hline $\begin{array}{l}\text { Loss of precious natural } \\
\text { resources/habitat }\end{array}$ & & & & & 1.86 & 1.86 & 1.77 & 1.86 & 1.86 & Small Impact \\
\hline Loss of biodiversity & & & & & 1.86 & & & 1.86 & 1.86 & Small Impact \\
\hline Damage to waterways & & & & & & 2.09 & 2.05 & & & Small Impact \\
\hline $\begin{array}{l}\text { Adverse effects on } \\
\text { other water use }\end{array}$ & & & & & 1.82 & 1.86 & 1.77 & & & Small Impact \\
\hline $\begin{array}{l}\text { Adverse effects on aquaculture } \\
\text { and downstream water quality }\end{array}$ & & & & & & 1.86 & 1.82 & & & Small Impact \\
\hline Hazards to endangered species & & & & & & 1.77 & & & & Small Impact \\
\hline $\begin{array}{c}\text { Impediment of wildlife/loss of } \\
\text { valuable wildlife }\end{array}$ & & & & & & & & 1.77 & & Small Impact \\
\hline Long term environmental loss & & & & 2.00 & 2.05 & & & & & Small Impact \\
\hline Critical for species growth & & & & & & & & 1.77 & & Small Impact \\
\hline $\begin{array}{l}\text { Loss of aesthetic value/loss of } \\
\text { environmental scenic value }\end{array}$ & 1.86 & & & & & 1.95 & 1.82 & & & Small Impact \\
\hline $\begin{array}{c}\text { Impairment of } \\
\text { beneficial water uses }\end{array}$ & 1.77 & 1.91 & 1.77 & & & 1.82 & & & & Small Impact \\
\hline Loss of precious ecology & & & & & 1.77 & & & & & Small Impact \\
\hline Disease hazards & & & 1.77 & & & & & 1.86 & & Small Impact \\
\hline $\begin{array}{l}\text { Adverse impact on quality of } \\
\text { water for new settlers \& } \\
\text { downstream users }\end{array}$ & & & & & & 1.77 & & & & Small Impact \\
\hline $\begin{array}{l}\text { Disruption in periodicity of } \\
\text { water flow \& changes in water } \\
\text { quantity and quality }\end{array}$ & & & & & & 1.77 & & & & Small Impact \\
\hline
\end{tabular}

The average scores of the checklist ranged from 1.05 - 2.09. Most of the average scores fall within the range of no significant impact at $1.01-1.75$. Table 5 shows the results of the checklist that was answered by the respondents. There were only 32 boxes among the 546 boxes of the matrix that fall within the small impact at the range of $1.77-2.09$ which are the consequences of the causes of degradation of the river ecosystem. These are the loss of precious natural resources/habitat, adverse effects on other water use, adverse effects on aquaculture and downstream water quality, loss of aesthetic value/loss of environmental scenic value, impairment of beneficial water uses, adverse impact on quality of water for new settlers \& downstream users, disruption in periodicity of water flow \& changes in water quantity and quality. This means that the ecosystem of 
the Amburayan River in Kapangan, Benguet is not so much degraded by the anthropogenic activities and environmental disturbances in the place.

\subsection{Pollution}

Pollution is one of the sources of ecosystem degradation of the Amburayan River in Kapangan, Benguet. There are five main sources of pollution in the area and these are the solid waste, oil spill, toxic chemical hazard, mine tailing and mine drainage pollution.

It was related by the participants during the conduct of the FGD that the river is utilized in multi-purpose functions. Some of the uses of the river are: 1) fishing as source of food and livelihood; 2) agriculture as source of irrigation; 3) tourism and recreation; and 4) domestic use such as bathing and laundry. Some community members also conduct gold panning in the river. These activities are the potential sources of solid waste presence in the river. Oil spill was caused by mining operation in the area.

\subsection{Soil Erosion}

Among the sources of environmental degradation, soil erosion has most number of environmental damages. One of the reasons is that it is attributed both from anthropogenic activities and natural disturbances. Quarrying, land development, reclamation and construction of infrastructures are some of the human activities that cause soil erosion. On the other hand, earthquakes and typhoons are the phenomenon and natural disturbances that leads to soil erosion.

Soil erosion adversely affects the ecosystem of the Amburayan River because there are breeding, spawning or nursing grounds of the stocks that could be damaged due to this. In addition, the soil also mixed with water and may suffocate the macro aquatic species of the river and alter the natural habitat. Soil erosion affects the systemic processes of the lotic ecosystem such as water flow, quality and quantity.

\subsection{Sedimentation}

Sedimentation is also observed as a source of degradation. It has the effects to the environment compared to soil erosion. It has only smaller scope and these are: 1) loss of precious natural resources/habitat; 2) adverse effects on other water use; 3) adverse effects on aquaculture and downstream water quality; and 4) loss of aesthetic value/loss of environmental scenic value. There are specific areas where the macro aquatic species use as breeding, spawning, nursing grounds or even make it as habitat. When sedimentation occurs into these areas, it is not only the area that will be affected but more of the stocks that refuge in these.

\subsection{Dynamite Fishing}

Dynamite fishing is not conducted in the study area. However, most of the respondents considered the stretch of the Amburayan River in the downstream ba- 
rangay and municipality as they answered the checklist. The community of some barangays that traverse the downstream Amburayan River is noted for their illegal practices such as electro-fishing and dynamite fishing. With this, dynamite fishing surfaced to be one of the sources of environmental degradation that has a small impact in the ecosystem of the Amburayan River.

\subsection{Inorganic Fertilizer Run-Off Hazard}

The fishermen from the study area also conduct farming activities. Most of their time is allotted to farming and application of inorganic fertilizer is sometimes integrated in their practices. With this, run-offs drain to the small tributaries of the Amburayan River where some of the macro aquatic species niche into it. In any case, species that cannot tolerate such chemicals may experience mortality and the affected habitat may not be useful for other stocks to thrive.

\subsection{Identification and Documentation of Indigenous Conservation Measures of Biodiversity and the River Ecosystem}

According to the result of the interview during the conduct of the FGD, the community members related that they do not remember any traditional means of conserving and managing the river even before the time of their being.

Fortunately, the absence of indigenous management measures in maintaining the ecological integrity of the river is substituted by the traditional fishing practices, methods and gears of the community, which are thought to be environment friendly. This also explains that these fishing practices, methods and gears are not detrimental to the aquatic ecosystem in general. In addition, these mechanisms that are being used by the community allow optimum exploitation of the ecosystem and permit its biomass to be sustainably productive over the years.

Farming is still the major livelihood of the community next to fishing and farm labor or construction labor. The result of the FGD showed that $80 \%, 18 \%$ and $2 \%$ of their time are devoted to farming, fishing and labor, respectively. Participants of the FGD also said that the income or economic contribution of their livelihood activities are 75\%, 20\% and 5\% for farming, fishing and labor, respectively.

According to the participants of the FGD, the peak months of fishing are from March to June. The water depth of the river on the months of March and April is shallow as the temperature starts to increase. It is also observed that there is a shallow water level of the river in the months of December to February. Natural food production in the river ecosystem is also high in these months. These factors enable the fishermen to conduct their fishing practices such as "sarep", "sawil", "tunuton", "sillag", and "luy-loy". Shallow water level hastens fishing with the use of these practices.

On the other hand, warmer water and higher natural food production triggers the stimulus of the fish to end their dormant periods. This allows the fishermen 
to catch high volumes of fish not only in terms of individuals but also by weight. However, even when the water level is shallow during the months of December to February, the natural food production as well as the water temperature during these months is relatively low.

As the onset of the rainy season starts on the month of May, the high volume of fish catch is also maintained during this time with the use of the traditional fishing gear locally called as "asar". Commonly used but are customized and improvised fishing gears are also set along the river channel during this period.

The peaks of fish catch ends on the month of June as soon as the fish stocks from the upstream tributaries of the river are caught. The heavy rains facilitate the stocks to be carried going to the downstream as the water level rises. Other species biologically take advantage of the river water rise for migration and reproduction. With this, some of the stocks are caught in the fishing gears that are set along the river channel. After few numbers of consecutive rises of the river's water level, fish catch begin to decrease again. Fish catch falls from July to February at proper timing with the demand of farming activities of the community.

The positive factors that are present, implemented and utilized in the Amburayan River, Kapangan, Benguet are not an assurance and security of having a healthy and sustainable aquatic ecosystem. Proper and preventive management and conservation measures are still needed to mitigate the environmental problems that are brought by developmental actions, thus, preventing the ecosystem from collapsing.

\section{Summary}

This study was conducted to assess the biodiversity of macro aquatic species in Amburayan River in Kapangan, Benguet. It includes the identification of macro aquatic species present, inventory of fishing gears and practices being utilized, evaluation of anthropogenic and environmental sources and level of impacts on the river ecosystem and documentation of traditional management measures.

Five stations were assigned along the channel of Amburayan River from the head point of Station $1\left(16^{\circ} 36^{\prime} 56.78^{\prime \prime} \mathrm{N}, 120^{\circ} 37^{\prime} 30.86^{\prime \prime} \mathrm{E}\right)$ to the tail point of Station $5\left(16^{\circ} 38^{\prime} 39.68^{\prime \prime N}, 120^{\circ} 36^{\prime} 19.26^{\prime \prime E}\right)$. Sampling was done three times in 3000 $\mathrm{m}^{2}$ total area of the five stations. There were seven different types of fishing gears used ("tabukol", "baniit", "bukatot", "pana", "bagekbek" and "balchew") and three fishing practices ("sarep", "sawil" and "luy-loy") conducted to gather the macro aquatic species found in the river ecosystem. In addition, there were other fishing practices documented such as "sillag" and "tunuton"; The collected macro aquatic species was described and documented. Each species was also identified up to species level, however, some species were only identified up to the family level due to the insufficient references available. Samples were also submitted to the National Fisheries Research and Development Institute (NFRDI) for DNA analysis but the institute cannot accommodate the identification due to the absence of reagents for the processing of the analysis.

The available macro aquatic species in the Amburayan River is comprised of 
nine finfish species: Giant Mottled Eel (A. marmorata), Indonesian Short-fin Eel ( $A$. bicolor), Mosquito fish (G. affinis), Nile Tilapa (O. niloticus), Japanese Rainbow Goby (L. armatus), Bar-eye Goby (G. giuris), Loach Goby ( $R$. aspro), Red-tailed Goby (S. lagocephalus) and "Wadingan" (Rhinogobius sp.); one of which was not able to be identified due to insufficient references and reagents for DNA analysis. There were also three prawn species: Freshwater Prawn (Macrobrachium sp.), Madagascar Scale Prawn (M. lepidactylus) and Wood Shrimp (A. moluccensis). One of the crustaceans collected locally called as "Gakki" was only identified up to genus level (Sundathelphusa sp.). There is also a gastropod species that was caught and identified as Mahogany Trumpet Snail (M. maculata).

The ecological parameters of the Amburayan River were also evaluated. The result of the assessment showed that in terms of Relative Frequency (RF), "gakki" (23.67\%), "udang" (23.19\%) and "wadingan" (21.26\%) gained the highest values. However, "wadingan" got the highest value with respect to Relative Dominance (RDo) at $37.65 \%$ followed by "udang" and "gakki" at $32.45 \%$ and $29.84 \%$, respectively. The same species obtained the highest values in terms of Relative Density (RD) with 32.24\%, 31.79\% and 30.48\% for "wadingan", "udang" and "gakki", respectively. "Wadingan" (93.15\%), "udang" (87.42\%) and "gakki" (84.00\%) got the highest Importance Value Indices (IVI).

The Amburayan River has very low diversity for the Species Diversity Index (SDI) value is only 1.28. This means that the Amburayan River ecosystem has low biodiversity and it is attributed to human activities such as pollution and proliferation of introduced species such as "gakki" which serve as predators of small fishes. However, the populations of stocks collected have a promising value of 5216 individuals with a total biomass of $32.031 \mathrm{~kg}$.

There were no indigenous or traditional management practices that were implemented and being implemented in the Amburayan River to conserve its ecological integrity as well as its biodiversity. The participants related that only their traditional and customized fishing gears were used in the exploitation of the stocks.

The participants also said that there were only a few number of macro aquatic species present in the Amburayan River even before the operation of the Western Minolco Mines/Boneng Mines in the 1980s. They added that fishing activities were not conducted for two decades because of the incident that happened in which the dam site of the said mining company collapsed. The pollution from mine tailings and wastes of the mining company totally degraded the river ecosystem. It was only in the late 2010 that fishing became one of their activities again because they observed that the macro aquatic species of the river is able to inhabit the river ecosystem again. They also observed that some of the indigenous species that were caught before were substituted by other stocks.

There were only five sources of environmental degradation that were identified by the respondents and these give small impacts on the environment such as pollution, soil erosion, sedimentation, dynamite fishing and inorganic fertilizer run-off hazard which scored at the range of 1.77 to 2.09 . 


\section{Conclusion}

There is a low biodiversity of macro aquatic species present in the Amburayan River in Kapangan, Benguet because of the presence of introduced species, illegal fishing practices in the downstream tributaries of the river and mining activities within the watershed areas. There are no indigenous or traditional management measures conducted in the river ecosystem to conserve the river and its biodiversity, however, the fishing practices and gears utilized in the river ecosystem promote sustainability of the macro aquatic species inhabiting the environment. Anthropogenic activities and environmental disturbances identified in the area had low impacts to the Amburayan River ecosystem in Kapangan, Benguet.

\section{Recommendations}

1) Conduct the same assessment activities regularly in other areas of the Amburayan River.

2) Formulate, consult, approve and implement potential policies, management strategies and actions that would prevent the degradation of the Amburayan River.

3) Establish sanctuary areas in Amburayan River to provide a protected place for the stocks to spawn and reproduce.

4) Conduct captive breeding and production of macro aquatic species present in the Amburayan River for aquaculture and stock enhancement purposes as well as for ex-situ conservation.

5) DNA analysis should be done for the proper identification of macro aquatic species present in the Amburayan River for accurate identification.

Analysis of heavy metals in water should also be conducted to monitor the quality of water in the river.

\section{References}

[1] Valencia, L.B. (2002) The Cordilleras: Watershed Cradle of the Philippines. http://www.travelsmart.net/article/105003

[2] Philippine Statistics Authority (PSA) (2015) 2006-2015 Country Stat Philippines. Regional Profile: Cordillera Administrative Region.

http://countrystat.bas.gov.ph/?cont=16\&r=14

[3] Casal, C.M.V. (2006) Global Documentation of Fish Introductions: The Growing Crisis and Recommendations for Action. Biological Invasions, 8, 3-11. http://link.springer.com/article/10.1007/s10530-005-0231-3 https://doi.org/10.1007/s10530-005-0231-3

[4] Dudgeon, D., et al. (2006) Freshwater Biodiversity: Importance, Threats, Status and Conservation Challenges. Biological Reviews, 81, 163-182. http://onlinelibrary.wiley.com/doi/10.1017/S1464793105006950/abstract https://doi.org/10.1017/S1464793105006950

[5] WWF. Undated. Philippines Freshwater. http://wwf.panda.org/about_our_earth/ecoregions/philippines_\%20freshwater.cfm

[6] Earth Trends (2003) Vedra. In: Alberto, A.M.P., Ed., Biodiversity, Environmental Management Institute (EMI), Central Luzon State University (CLSU), Science City 
of Munoz, Nueva Ecija, 233.

[7] Barut, N. (2014) Overview of National Stock Assessment Program (NSAP). National Fisheries Research and Development Institute NFRDI, Quezon City.

[8] CPA (2004) Cordilleras Water Resources. http://www.cpaphils.org/cordillera/watersources.htm

[9] Romero, M.A.V. (2006) Survey of Indigenous and Introduced Species in the Freshwater Ecosystems in Pampanga. Master's Thesis, Central Luzon State University, Science City of Munoz, Nueva Ecija.

[10] Benas, M.T.B. (2012) Save the Abra River Project to Save "Ludong" too. http://news.abrenian.com/2012/11/05/save-the-abra-river-project-to-save-ludong-t oo/

[11] Choulamany, X. (2011) Integrating Inland Fisheries Management in Southeast Asia Towards 2020: Issues and Perspectives. Proceedings of the ASEAN-SEAFDEC Conference on Sustainable Fisheries for Food Security towards 2020, II, 285-292.

[12] Paller, V.G.V., et al. (2011) Freshwater Fish Fauna in Watersheds of Mt. Makiling Forest Reserve, Laguna, Philippines. Philippine Journal of Science, 140, 195-206

[13] Fermin, L.J.B., et al. (2014) Inventory of Commercially Important Fish Species Fish Species of Abra River, Cordillera. National Stock Assessment Program, Bureau of Fisheries and Aquatic Resources-Cordillera Administrative Region, Quezon City.

[14] Food and Agriculture Organization (FAO) (1995) Code of Conduct for Responsible Fisheries. United Nations, Rome.

[15] BFAR-CAR (2014) Briefer on 2013 Cordillera Administrative Region Fishery Profile. BFAR-CAR, Baguio City.

[16] Alberto, A.M.P. (2005) Biodiversity. Environmental Management Institute (EMI), Central Luzon State University (CLSU), Science City of Munoz, 233.

[17] Cordillera Peoples Alliance (CPA) (2004) Cordilleras Water Resources. http://www.cpaphils.org/cordillera/watersources.htm

[18] Manacop, P.R., (1953) The Life History and Habits of the Goby, Sicyopterus extraneus Herre (Anga) Gobiidae with an Account of the Goby-Fry Fishery of Cagayan River, Oriental Misamis. Phil. J Fish., 2, 1-60. http://www.fishbase.se/references/FBRefSummary.php?ID=110258

[19] Froese, R. and Pauly, D. (Eds.) (2014) FishBase. World Wide Web Electronic Publication. http://fishbase.sinica.edu.tw/

[20] Kottelat, M. (2013) The Fishes of the Inland Waters of Southeast Asia: A Catalogue and Core Bibliography of the Fishes Known to Occur in Freshwaters, Mangroves Andestuaries. The Raffles Bulletin of Zoology, 2013, 1-663.

[21] Matsuda, H., Amaoka, K., Araga, C., Uyeno, T. and Yoshino, T. (1984) The Fishes of the Japanese Archipelago. Tokai University Press, Tokyo, 437.

[22] Nakhodai, S., Kamrani, E. and Mirzadeh. M. (2013) A Study on the Diet Composition of the Marsh Crab Sartorianarokitanskyi in Geno, Southern Iran. Nationalparl-Forschung in Der Schweiz (Switzerland Research Park Journal), 102, No. 5.

[23] Yeo, D.C.J., Ng, P.K.L., Cumberlidge, N., Magalhaes, C., Daniels, S.R. and Campos, M.R. (2008) Global Diversity of Crabs (Crustacea: Decapoda: Brachyura) in Freshwater. Freshwater Animal Diversity Assessment. Hydrobiologia, 595, 275-286. https://doi.org/10.1007/s10750-007-9023-3

[24] Sharma, A. and Subba, B.R. (2005) General Biology of Freshwater Prawn, Macrobrachiumlamarrei (H. Milne-Edwards) of Biratnagar. Our Nature Nepal, 3, 31-41. 